Conference Proceedings Paper

\title{
Impact of Wildfires on Atmospheric Ammonia concentrations in the US: Coupling Satellite and Ground Based Measurements
}

\author{
Casey D. Bray ${ }^{1, *}$, William Battye ${ }^{1}$, Viney P. Aneja ${ }^{1}$, Daniel Tong ${ }^{2,3,4}$, Pius Lee ${ }^{2}$ and \\ Youhua Tang ${ }^{2,3}$ \\ 1 North Carolina State University, Raleigh, NC 27695, USA; whbattye@ncsu.edu (W.B.); \\ vpaneja@ncsu.edu (V.P.A.) \\ 2 NOAA Air Resources Laboratory, 5830 University Research Court, College Park, \\ Maryland, MD 20740, USA; daniel.tong@noaa.gov (D.T.); pius.lee@noaa.gov (P.L.); \\ youhua.tang@noaa.gov (Y.T.) \\ 3 Cooperative Institute for Climate and Satellites, University of Maryland, College Park, \\ Maryland, MD 20740, USA \\ 4 Center for Spatial Information Science and Systems, George Mason University, Fairfax, \\ Virginia, VA 22030, USA \\ * Correspondence: cdbray@ncsu.edu; Tel.: +1-336-684-7712
}

Published: 15 July 2016

\begin{abstract}
Gaseous ammonia plays a crucial role in the earth's atmosphere. Major sources of atmospheric ammonia include agriculture and fires. As the climate continues to change, the pattern of fires across the US will also change, leading to changes in ammonia emissions. This study examines four major science questions using satellite and in-situ data from 2010-2014: (1) How have concentrations of ammonia changed across the US? (2) How have the strength and frequency of fires changed? (3) How has this change in fires impacted ammonia emissions? (4) How does the US EPA NEI compare with the calculated emissions? Satellite and in-situ data were used to evaluate the annual concentrations of ammonia and to calculate the total ammonia emissions across the continental US. The results of this study showed that ammonia concentrations have slightly increased over the five-year period. The total fire number and the average fire radiative power have decreased, while the total yearly burn area has increased. The calculated ammonia emissions from fires on a national scale show an increasing trend and when compared with the US EPA NEI for ammonia emissions from fires, annual ammonia emissions are, on average, a factor of 0.49 higher than the NEI.
\end{abstract}

Keywords: ammonia; wildfires; biomass burning; ammonia emissions; National Emissions Inventory; fires; fire emissions

\section{Introduction}

Ammonia $\left(\mathrm{NH}_{3}\right)$ is an important gas in the atmosphere. $\mathrm{NH}_{3}$ reacts with sulfuric, nitric and hydrochloric acids to form ammonium sulfate, ammonium bisulfate, ammonium nitrate, ammonium chloride aerosols which contribute to fine particulate matter [1-5]. Fine particulate matter, or $\mathrm{PM}_{2.5}$, is particulate matter with an aerodynamic diameter less than 2.5 micrometers. Exposure to elevated $\mathrm{PM}_{2.5}$ concentrations is considered to be a major concern for human health and welfare due to the particles' ability to penetrate deep into the respiratory tract. There are many adverse health effects 
The 1st International Electronic Conference on Atmospheric Sciences (ECAS 2016), 16-31 July 2016;

Sciforum Electronic Conference Series, Vol. 1, 2016

associated with elevated concentrations of fine particulate matter, such as chronic bronchitis, aggravated asthma, irregular heartbeat, other cardiovascular and respiratory issues and even death [6-8] Fine particulate matter is also associated with a number of environmental impacts, such as reducing visibility and changing the earth's radiational balance [7-10]. With decreasing concentrations of sulfur dioxide and nitrous oxides in the atmosphere, the partitioning between gas and particle phase for ammonia and ammonium will be altered [11-12]. This will lead to a larger concentration of gaseous atmospheric ammonia [4]. Gaseous ammonia can be deposited to the surface, which leads to ammonification, eutrophication and a loss of biodiversity $[1,4,5,13]$. Increased concentrations of ammonia can also lead to a decreased resistance to drought and frost damage [1]. Ammonia also plays a role in the formation of nitrous oxide, which is a major greenhouse gas.

Major sources of atmospheric ammonia include ammonia based fertilizers, animal waste and biomass burning, with intensely managed livestock and agricultural sources of ammonia contributing most to ammonia concentrations [13,15-17]. According to the US Environmental protection Agency (EPA) National Emission Inventory (NEI) (2011), fires account for a total of about $17 \%$ of ammonia emissions in the western US (Regions 9 and 10) and about $8 \%$ of all ammonia emissions nationwide [18]. Biomass burning is an important source of ammonia emissions, but the strength of the source remains poorly quantified $[5,19]$. Ammonia is emitted into the atmosphere during smoldering combustion, which occurs in slow, low temperature fires without a flame [5,13,19-23].

As the earth's climate changes, higher concentrations of ammonia are expected due to an increase in emissions. [24] found that ammonia concentrations were two orders of magnitude larger than background levels during the summer of 2010, which was the hottest and driest summer on record (until 2015), when wildfires ran rampant across Europe and Russia. Hot and dry conditions in the Mediterranean countries, Australia and the western United States have contributed to an increase in wildfire activity, thus increasing the emission of gaseous ammonia, among other pollutants, into the atmosphere [19] [25] also observed unusually high concentrations of ammonia across the southeastern United States (US) during 2007, when fires were prevalent due to increased temperatures and widespread drought. Higher temperatures and widespread drought are expected to lead to an increase in the number of observed wildfires across many regions, such as the southeastern United States, the northern great plains, the Pacific coast, the southwestern US and the southern Rockies [19,25-32]. However, due to changes in relative humidity and wind speeds, the future fire potential in the northern Rockies and the northwestern United States may likely be reduced [28].

The primary objectives of this study were to identify trends in ammonia concentrations, ammonia emissions from biomass burning, which includes wildfires, agricultural burns and prescribed burns, and trends in fire strength/frequency across the United States (US) from 2010 to 2014. In addition to this, a secondary objective was to determine how close the calculated ammonia emissions from biomass burning were to the US Environmental Protection Agency (EPA) National Emissions Inventory (NEI) for 2011. These objectives were addressed by answering four major science questions using a combination of in-situ based and satellite data: (1) How have concentrations of ammonia changed across the US from 2010 to 2014? (2) How have the strength and frequency of fires changed during this period? (3) How has this change in fires impacted ammonia emissions? (4) How does the US EPA NEI compare with the calculated emissions?

\section{Data and Methods}

\subsection{Remote Sensing of NH3}

In order to determine trends in ammonia concentrations, both satellite and in-situ measurements were used. Satellite measurements were derived from the Tropospheric Emission Spectrometer (TES) on NASA's (National Aeronautics and Space Administration) Aura satellite for the continental United States (CONUS) for 2010-2014. TES measures the Earth's infrared light energy as well as the 
The 1st International Electronic Conference on Atmospheric Sciences (ECAS 2016), 16-31 July 2016;

Sciforum Electronic Conference Series, Vol. 1, 2016

particulates and gases within the atmosphere on a global scale. Observations are made on a 16-day cycle (making roughly 1 pass during the day and 1 pass during the night over each region every other day) $[33,34]$. TES has a spectral resolution of $0.025 \mathrm{~cm}^{-1}$, a spatial resolution of $0.53 \times 5.3 \mathrm{~km}$ and a nadir footprint of $5.3 \times 8.5 \mathrm{~km}$ [33]. Atmospheric ammonia concentrations are derived from TES by observing the difference in the infrared radiation intensity between $940 \mathrm{~cm}^{-1}$ and $970 \mathrm{~cm}^{-1}$ and then calculating the intensity of the radiation in the bands using a forward radiative transfer model. Finally, the meteorological conditions are applied to the assumed ammonia concentration to determine the atmospheric concentration of ammonia [35]. This study used only measurements which met the TES Species Retrieval Quality criteria and for which the degrees of freedom for signal (DOFS) exceeded 0.5.

The in-situ ammonia concentrations used in this study were obtained for 2010 through 2014 from the National Atmospheric Deposition Program (NADP) Ammonia Monitoring Network (AMoN). This network measures ammonia concentrations in 66 locations that span across the CONUS. The samples measured at the AMoN sites are taken in two week increments using Radiello passive samplers [36]. The measurements made in this study quality assured following the AMoN Standard Operating Procedures [37] by the scientists at the NDAP Central Analytical Laboratory

\subsection{Remote Sensing of Biomass Burning}

NASA's Fire Information for Resource Management System (FIRMS) was utilized to obtain archived fire locations, frequency and strength. This data was obtained from the Moderate Resolution Imaging Spectroradiometer (MODIS) sensor on NASA's Earth Observing System satellites (Terra and Aqua). The MODIS fire products are obtained using a fire detection algorithm that uses a multispectral contextual approach to leverage the mid-infrared radiations emitted by fires [38]. FIRMS delivers the MODIS fire data locations that represent the center of a $1 \mathrm{~km}$ pixel that is flagged by the algorithm as an area that contains at least one fire/hotspot within the pixel [38].

\subsection{Calculating $\mathrm{NH}_{3}$ Emissions from Biomass Burning}

To estimate emissions, the following equation [39-41] was used (Equation 1):

$$
E_{i}=A(x, t) \times B(x) \times F B \times E F_{i},
$$

where $\mathrm{E}_{\mathrm{i}}$ is the emission of species $\mathrm{i}$ (in this case, $\mathrm{NH}_{3}$ ), $\mathrm{A}$ is the area burned at time $\mathrm{t}$ and location $\mathrm{x}$, $\mathrm{B}$ is the biomass loading at location $\mathrm{x}, \mathrm{FB}$ is the fraction of that biomass burned in the fire and $\mathrm{EF}_{\mathrm{i}}$ is the emission factor of species $i$. It is important to note that all biomass terms are on a dry weight basis. In order to obtain the area burned, the MODIS Burned Area product was used. The data was downloaded in a shapefile format from the University of Maryland's website. The MODIS burned area product was validated by [42] who found that the MODIS product provided the most accurate burned area maps when compared with other products (L3JRC, GlobCarbon). The biomass loading, which is defined as the amount of biomass available that can be burned in each fire, was obtained from Table 1 in [39], which describes the total fuel loading assumptions for various land cover classifications based on the literature (Table 1).

In order to determine the biomass burning, it is necessary to know the type of land being burned. The MODIS Land Cover data product (MCD12Q1) was obtained from the University of Maryland's Global Land Cover Facility webpage (www.landcover.org). The fraction of biomass burned within the fire was estimated using the methods used by $[39,40,43]$. In this method, areas with $60 \%$ or more tree cover are given an FB value of 0.3 for the woody fuel and 0.9 for herbaceous cover. Areas with $40 \%-60 \%$ tree covers, the FB is 0.3 for woody fuels and the FB for herbaceous fuels can be calculated using the following equation (Equation 2):

$$
\text { FBherb }=e^{-0.13^{*} \text { FractionTreeCover }}
$$


The 1st International Electronic Conference on Atmospheric Sciences (ECAS 2016), 16-31 July 2016;

Sciforum Electronic Conference Series, Vol. 1, 2016

Finally, when the fraction of tree cover is less than $40 \%$, no woody fuel is assumed to burn and an FB value of 0.98 is given for herbaceous fuels [39,43]. The Advanced Very High Resolution Radiometer (AVHRR) Continuous Fields Tree Cover product was used, which was from the University of Maryland [44]. This product gives a percentage value for tree cover at a $1 \mathrm{~km}$ spatial resolution. The emission factor for ammonia was obtained from [40], who classified the emission factor with each land classification from the literature. Table 2 shows the emission factors used in this study, adapted from $[22,40]$.

Table 1. The biomass loading term $\left(\mathrm{kg} \cdot \mathrm{m}^{-2}\right)$ for each respective land classification type.

\begin{tabular}{cc}
\hline Land Classification & Biomass Loading [39] $\left.\mathbf{~} \mathbf{k g} \cdot \mathbf{m}^{-2}\right)$ \\
\hline Barren & 0.1 \\
Cropland & 0.5 \\
Deciduous Broadleaf Forest & 9.5 \\
Deciduous Needleleaf Forest & 12 \\
Evergreen Broadleaf Forest & 17 \\
Evergreen Needleleaf Forest & 14 \\
Grasslands & 1.1 \\
Mixed Forest & 12 \\
Open Shrublands & 4.3 \\
Closed Shrublands & 4.3 \\
Permanent Wetlands & 1.1 \\
Savannas & 1.1 \\
Woody Savannas & 1.1 \\
Snow/Ice & 0 \\
Urban & 0.1 \\
Water & 0 \\
\hline
\end{tabular}

Table 2. Ammonia emission factors from biomass burning of each respective land classification type [40].

\begin{tabular}{ccc}
\hline Land Classification & $\begin{array}{c}\mathbf{N H}_{3} \text { Emission Factor } \\
\text { (g.kg Biomass Burned }\end{array} \mathbf{~}^{\mathbf{1}}$ ) & Reference \\
\hline Evergreen Needleleaf Forest & 3.5 & {$[22,40]$} \\
Evergreen Broadleaf Forest & 0.76 & {$[22,40]$} \\
Deciduous Needleleaf Forest & 3.5 & {$[22,40]$} \\
Deciduous Broadleaf Forest & 1.5 & {$[22,40]$} \\
Mixed Forest & 1.5 & {$[22,40]$} \\
Closed Shrubland & 1.2 & {$[22,40]$} \\
Open Shrubland & 1.2 & {$[22,40]$} \\
Woody Savannas & 1.2 & {$[22,40]$} \\
Savannas & 0.49 & {$[22,40]$} \\
Grasslands & 0.49 & {$[22,40]$} \\
Permanent Wetlands & 0.49 & {$[22,40]$} \\
Croplands & 2.3 & {$[22,40]$} \\
Croplands/Natural Vegetation Mosaic & 0.49 & {$[22,40]$} \\
Barren/Sparsely Vegetated & 0.49 & {$[22,40]$} \\
\hline
\end{tabular}

The calculated emissions of ammonia from biomass burning (Equation 1) were compared against the US EPA NEI on a national scale [45]. 
The 1st International Electronic Conference on Atmospheric Sciences (ECAS 2016), 16-31 July 2016;

Sciforum Electronic Conference Series, Vol. 1, 2016

\subsection{Meteorology Data}

Meteorology is an integral part the earth system. Because of this, it is important to consider meteorological phenomena when examining fires as well as atmospheric ammonia concentrations. Two major meteorological parameters were used in this study: monthly average temperature and monthly total precipitation. This data was obtained from the National Oceanic and Atmospheric Administration (NOAA) National Centers for Environmental Information Climate Data website [46]. The data product used was the GHCND (Global Historical Climatology Network) Monthly Summary data for the CONUS from 2010-2014, which provided the total monthly precipitation (inches) and the monthly mean temperature $\left({ }^{\circ} \mathrm{F}\right)$. This data is described in detail in [47]. In order to ensure accuracy, only measurements that passed the NOAA National Climatic Data Center quality assurance check were used in this study.

\section{Results}

\subsection{Trends in Ammonia Concentration}

Satellite and in-situ measurements of ammonia were utilized to determine the trend in the concentrations of ammonia from 2010 to 2014 across the CONUS. Measurements from the AMoN network show ambient concentrations of $\mathrm{NH}_{3}$ increasing slightly (by a factor of 0.000027 ) from 2010 to 2014 on a national scale (Figure 1). In contrast to this, the $\mathrm{NH}_{3}$ retrieval from TES for the same period show an overall decrease (by a factor of 0.000033) in the ambient concentrations of $\mathrm{NH}_{3}$ on a national scale (Figure 2). However, when looking at the change in the $\mathrm{NH}_{3}$ retrieval from TES for 2011-2014, a slight increase (by a factor of 0.000029) in the $\mathrm{NH}_{3}$ concentration is evident (Figure 3). This increase is comparable to the increase in the national ambient concentration of $\mathrm{NH}_{3}$ measured by AMoN.

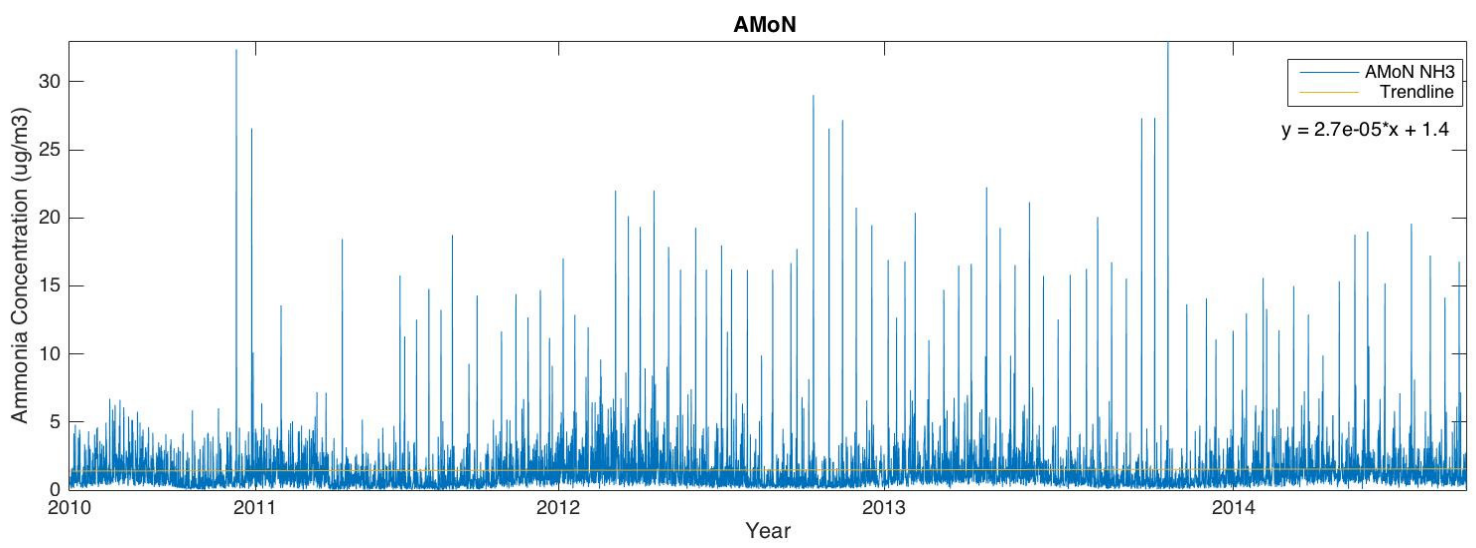

Figure 1. $\mathrm{NH}_{3}$ concentrations $\left(\mu \mathrm{g} \cdot \mathrm{m}^{-3}\right)$ measured as two-week averages across the continental United States from 2010 to 2014 are represented by the blue line while the gold line represents the trend line of this data. The linear equation displayed on the chart describes the plotted trend line (gold). 


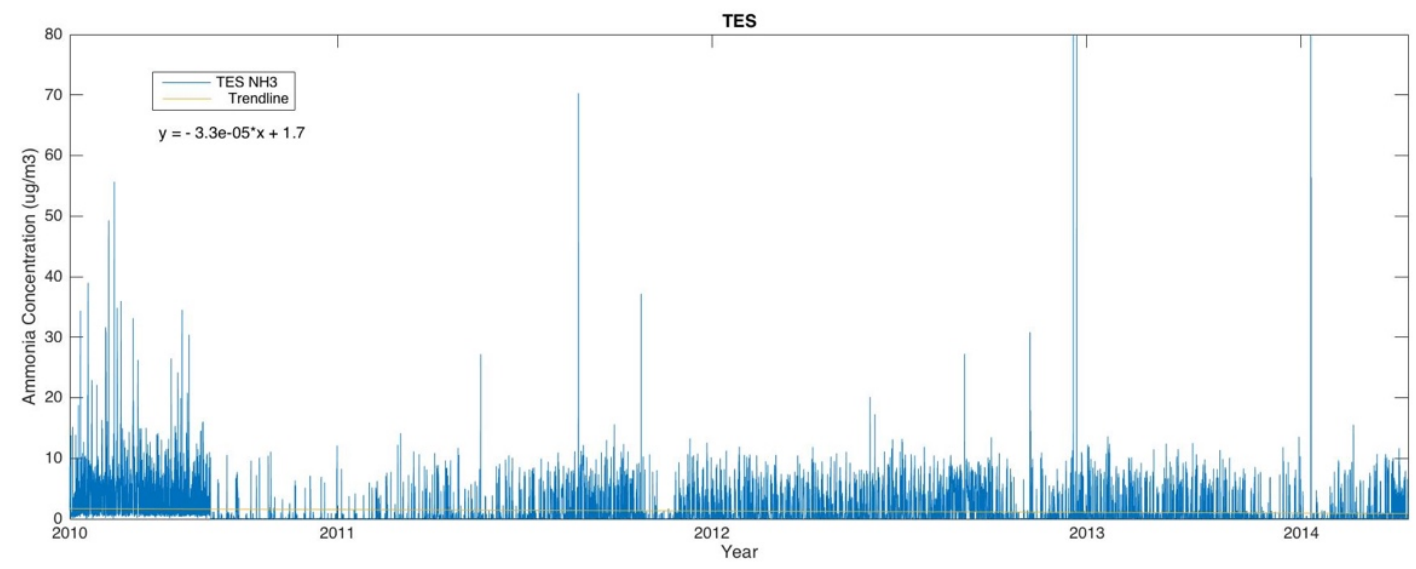

Figure 2. $\mathrm{NH}_{3}$ concentrations $\left(\mu \mathrm{g} \cdot \mathrm{m}^{-3}\right)$ retrieved from TES across the continental United States from 2010 to 2014 are represented by the blue line while the gold line represents the trend line of this data. The linear equation displayed on the chart describes the plotted trend line (gold).

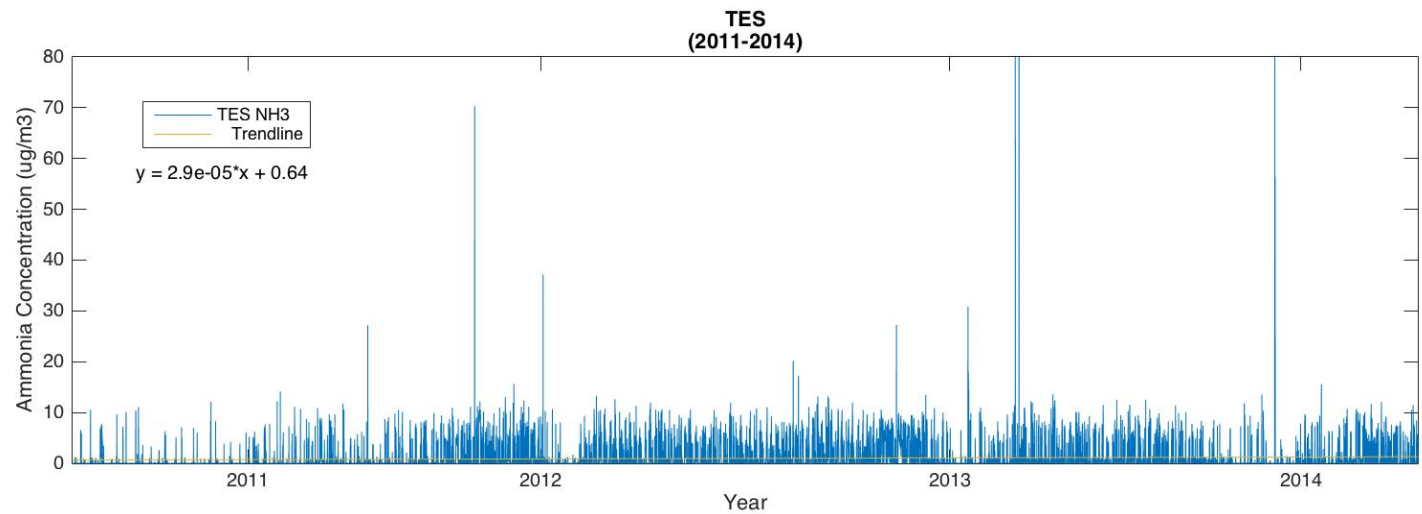

Figure 3. $\mathrm{NH}_{3}$ concentrations $\left(\mu \mathrm{g} \cdot \mathrm{m}^{-3}\right)$ retrieved from TES across the continental United States from 2011 to 2014 are represented by the blue line while the gold line represents the trend line of this data. The linear equation displayed on the chart describes the plotted trend line (gold).

While it is not possible to compare the AMoN measurements and the TES $\mathrm{NH}_{3}$ retrievals due to a difference in both spatial and temporal scales, it is possible to compare the general concentrations between each measurement technique. TES retrieval measurements tend to be higher than the AMoN measurements, which can be explained by the temporal range for the two measurements. The TES retrieval shows a snapshot concentration within the atmospheric column (at the ground level) while the AMoN measurement shows a two-week average. In addition to this, the AMoN monitors are not well distributed through the United States, with the central and western US having a much sparser distribution when compared with the eastern US (Figure 4). In comparison, the TES sensor has a much larger spatial coverage (Figure 4).

In addition to this, the higher measurements retrieved by TES can also potentially be explained by TES measurements taken over agricultural regions, which are known to emit large quantities of ammonia [17], due to the much larger spatial coverage of TES versus the AMoN network. 


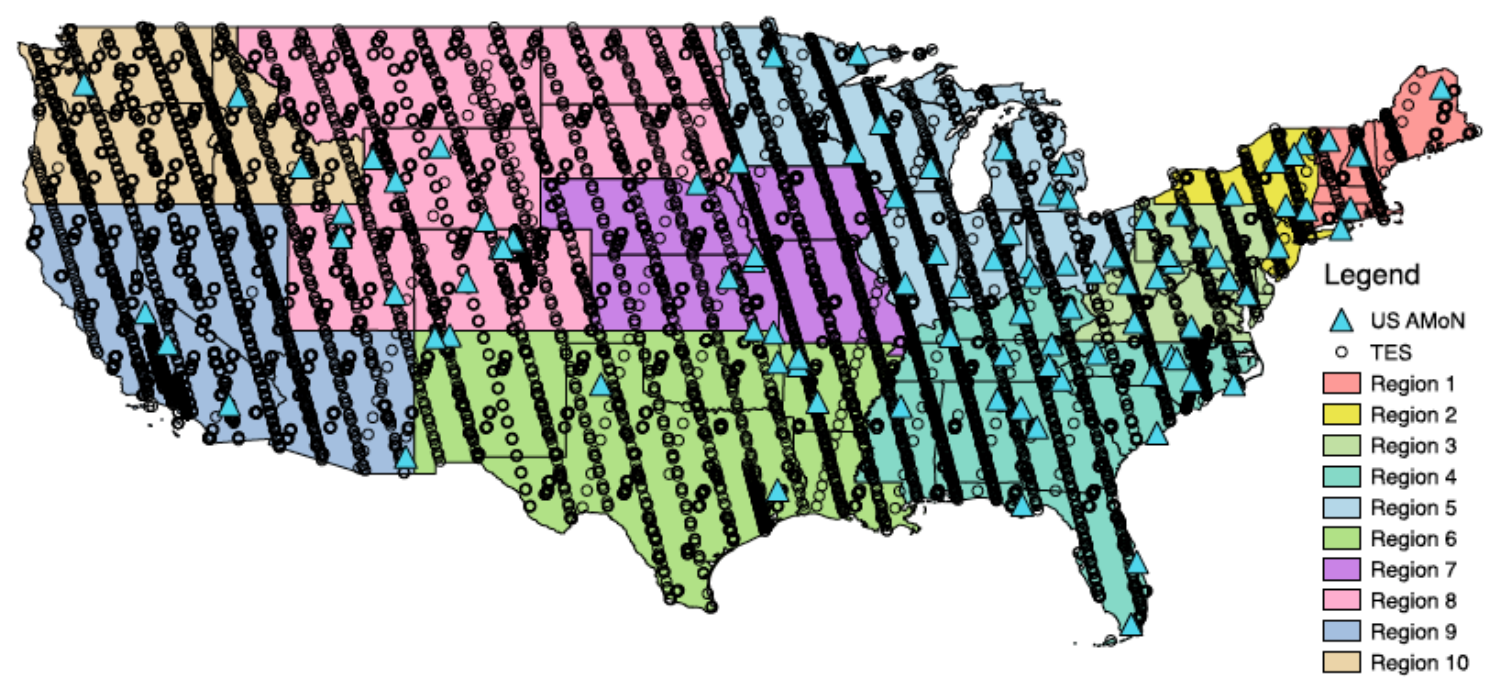

Figure 4. The TES track path represented by black circles plotted in ArcMap with all AMoN monitors (blue triangles) across the continental United States. Each US EPA region is represented by a different color.

\subsection{Trends in Biomass Burning}

On a national scale, the overall trend in the number of fires per year actually decreased by a factor of 1.6E4, with the lowest total number occurring in 2014 (Figure 5). The largest number of fires occurred in 2011 ( 2E5 fires), with the lowest number of fires occurring in 2014 ( 1.05E5 fires).

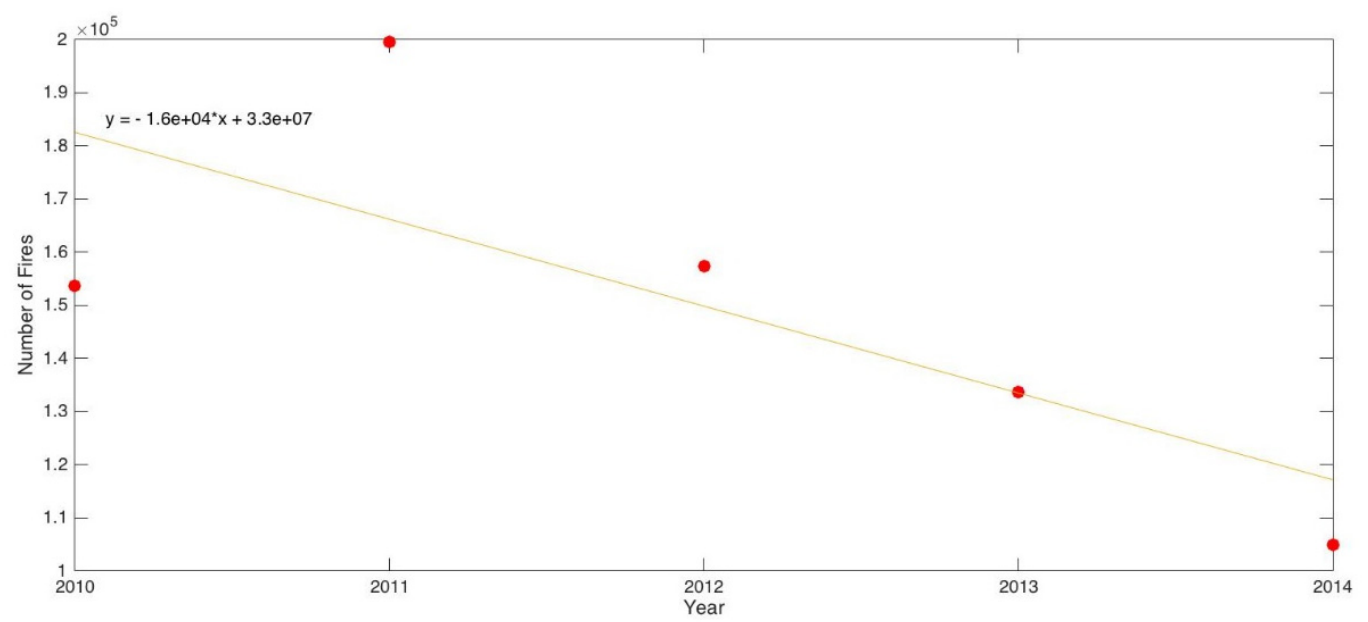

Figure 5. The total number of fires each year represented by red dots. The associated trend line is displayed as a gold line with the linear equation represented in black.

When looking at the fire number per year on a monthly basis, the annual trend in ammonia emissions is such that the peak number of fires occurs during the spring time with a smaller peak occurring in late summer (Figure 6).

When comparing the monthly number of fires across each year of interest, the month to month trends between each year show that the number of fires in 2010 actually peaked in the late summer, with the fire count around 22,011. In contrast to this, an enormous peak is observed in 2011 during the spring time, with the number of fires reaching approximately 43,931 . In contrast to this, the fire number decreased significantly in the summer months $(\sim 10,000)$. In 2012, two distinct peaks are evident: one in the spring $(\sim 27,277$ fires $)$ and one in the early summer ( 25,518 fires). The overall 
The 1st International Electronic Conference on Atmospheric Sciences (ECAS 2016), 16-31 July 2016;

Sciforum Electronic Conference Series, Vol. 1, 2016

number of fires appears to be higher month to month in 2013, with a peak in the spring ( 28,376 fires) and an even smaller peak in the late summer ( 15,374 fires). Finally, the number of fires in the spring of 2014 was lower than that of 2012 ( 19,667 fires) with a much smaller peak in the late summer ( 10,202 fires).

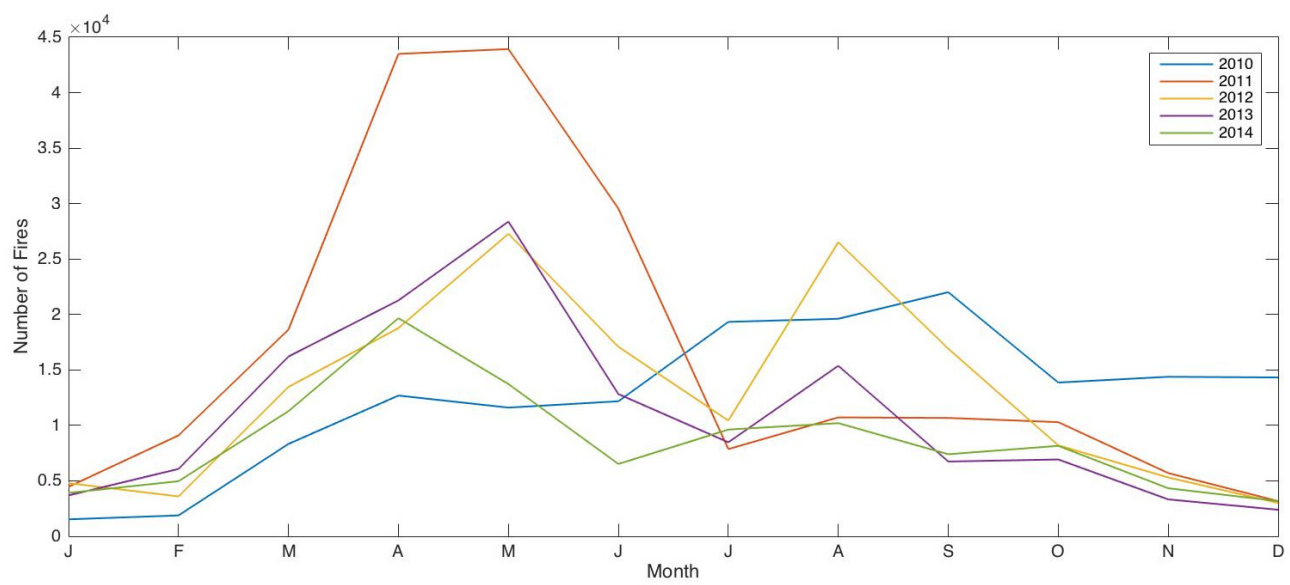

Figure 6. The monthly total number of fires for each year in the study. The monthly number of fires for 2010 is represented by the blue line, the monthly number of fires for 2011 is represented by the red line, the fires for 2012 is represented by the gold line, the fires for 2013 is represented by the purple line and the fires in 2014 is represented by the green line.

The overall yearly average radiative power of fires also decreased from 2010 to 2014 by a factor of 1.9 on a national scale (Figure 7). While 2012 (75.7 MW) and 2011 (73.7 MW) saw the highest average fire radiative power (FRP), the lowest FWP was observed in 2010 (64.9 MW). The variability of the average FRP on a monthly scale is much larger between the years than was observed in the fire number (Figure 8). The peak in the average monthly FRP in 2010 occurred in January (82.5 MW), with another peak occurring from May to September. In 2011, the peak in the average monthly FRP (88.7 MW) occurred in the summer and early fall. The highest monthly average FRP occurred in 2012, with the highest average monthly peak FRP (132.1 MW) occurring in February, with a smaller peak (92.6 MW) occurring in May. The peak average FRP (91.8 MW) in 2013 occurred in March, with secondary peaks in June and October with an average FRP of approximately $65 \mathrm{MW}$. Finally, in 2014, the peak FRP (79.3 MW) occurred in May with a secondary peak occurring in September (72.7 MW).

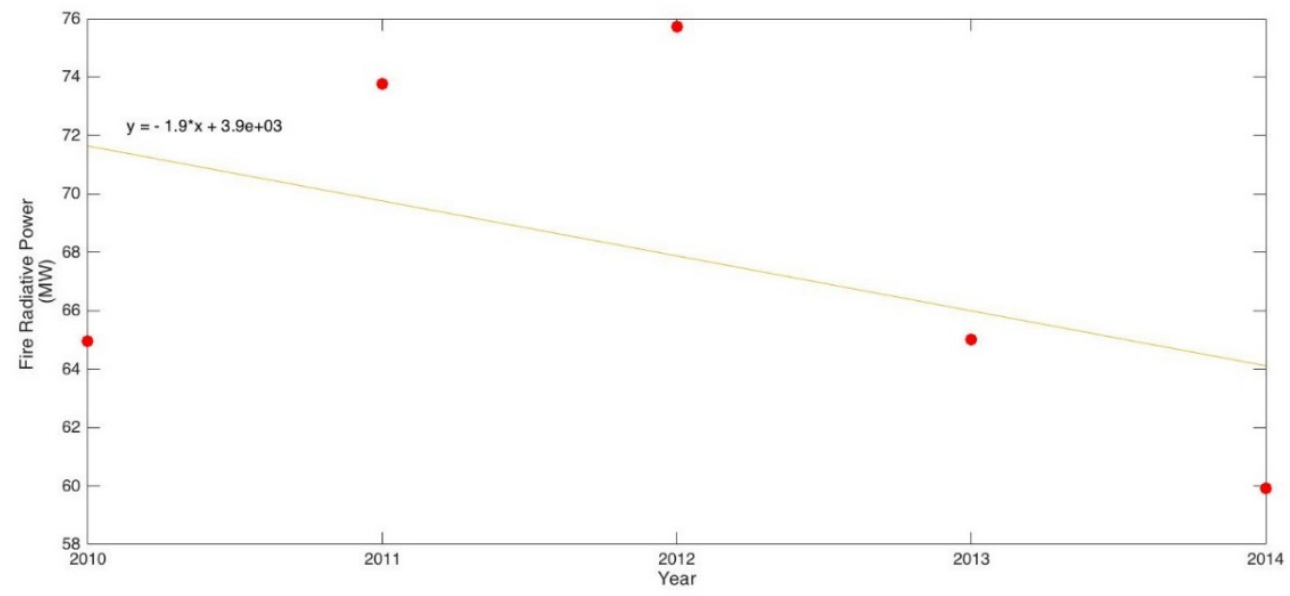

Figure 7. The average yearly fire radiative power $(\mathrm{MW})$ represented by red dots. The associated trend line is displayed as a gold line with the linear equation represented in black. 


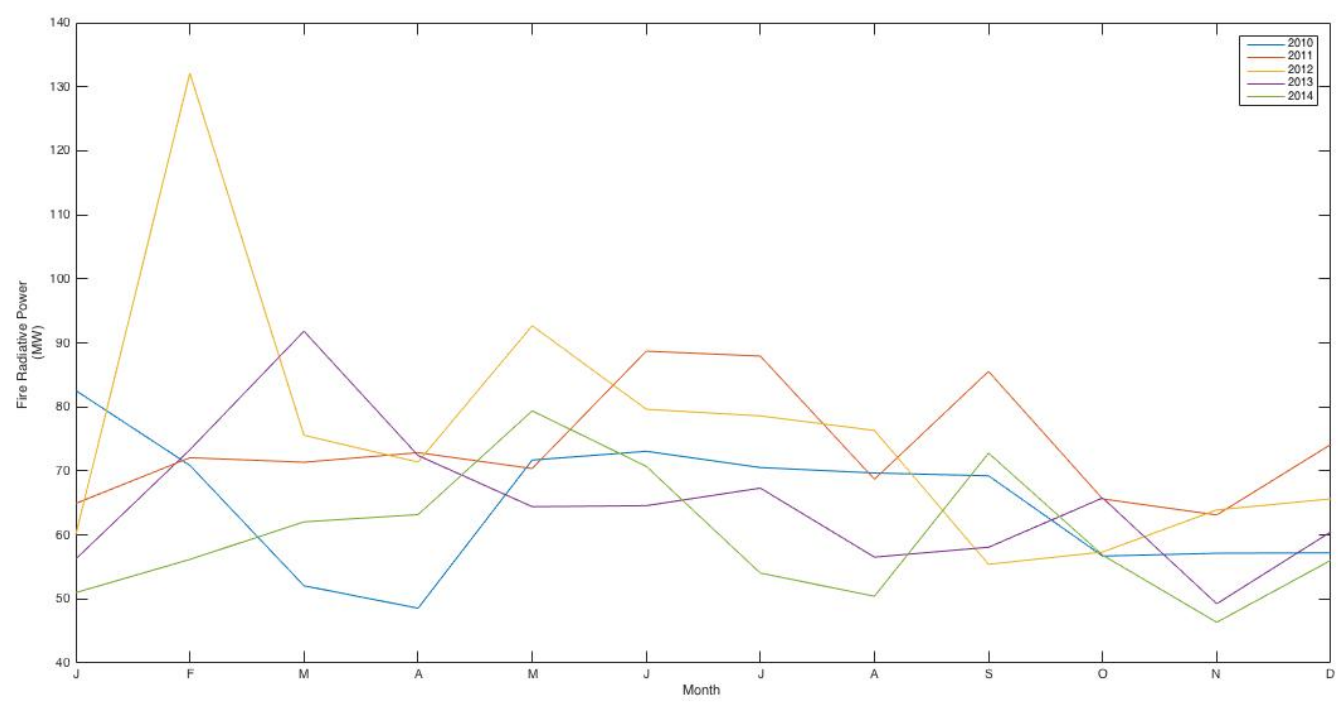

Figure 8. The monthly average fire radiative power (MW) for each year in the study. The monthly FRP for 2010 is represented by the blue line, the FRP for 2011 is represented by the red line, the FRP for 2012 is represented by the gold line, the FRP for 2013 is represented by the purple line and the FRP in 2014 is represented by the green line.

While there was an overall decrease in the total yearly fires and the average yearly FRP, there was an overall increase in the total burn area over the period (Figure 9). This suggests that while the national yearly total fires and national yearly average fire radiative power have decreased from 2010 to 2014 , the size of the fires actually increased. The total yearly burn area was the lowest in 2010 $\left(8.33 \mathrm{E} 10 \mathrm{~m}^{2}\right)$ and then the highest in $2011\left(3.08 \mathrm{E} 11 \mathrm{~m}^{2}\right)$, with the total burn area remaining fairly stable from 2012 to 2014 around $2 \mathrm{E} 11 \mathrm{~m}^{2}$. On a monthly scale, the peak burn area varies from year to year (Figure 10).

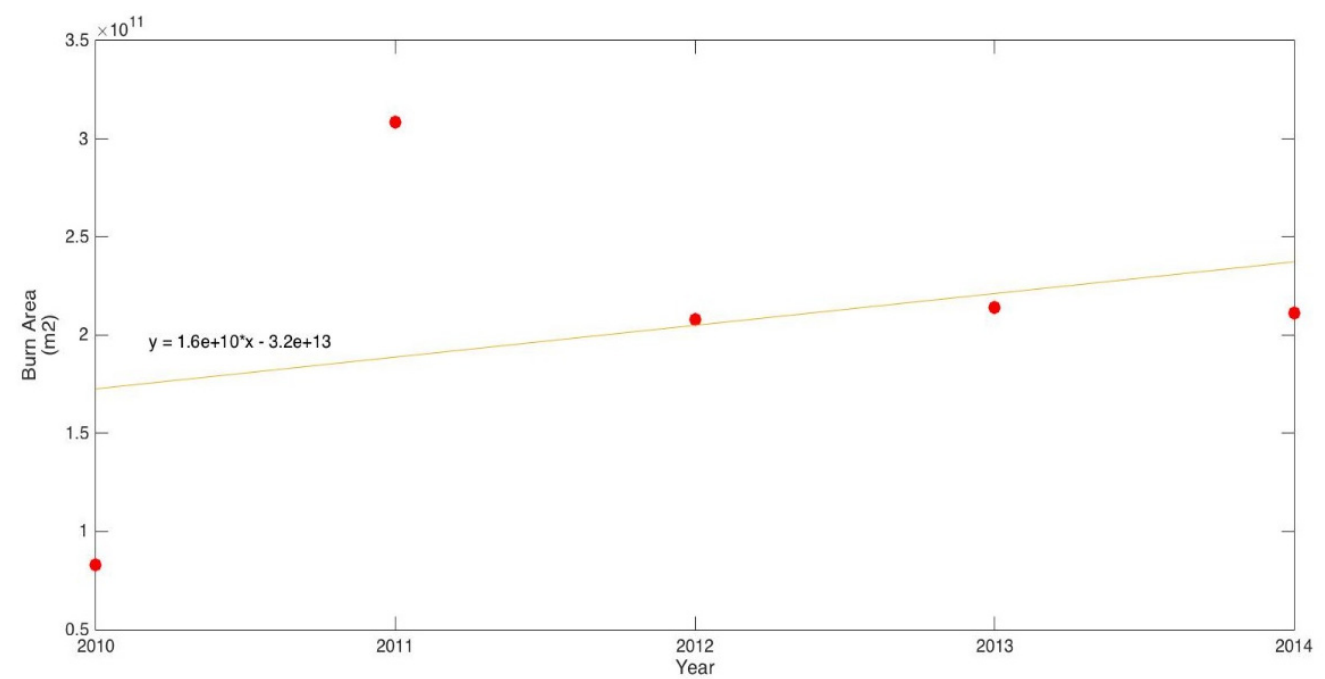

Figure 9. The total yearly burn area $\left(\mathrm{m}^{2}\right)$ represented by red dots. The associated trend line is displayed as a gold line with the linear equation represented in black. 


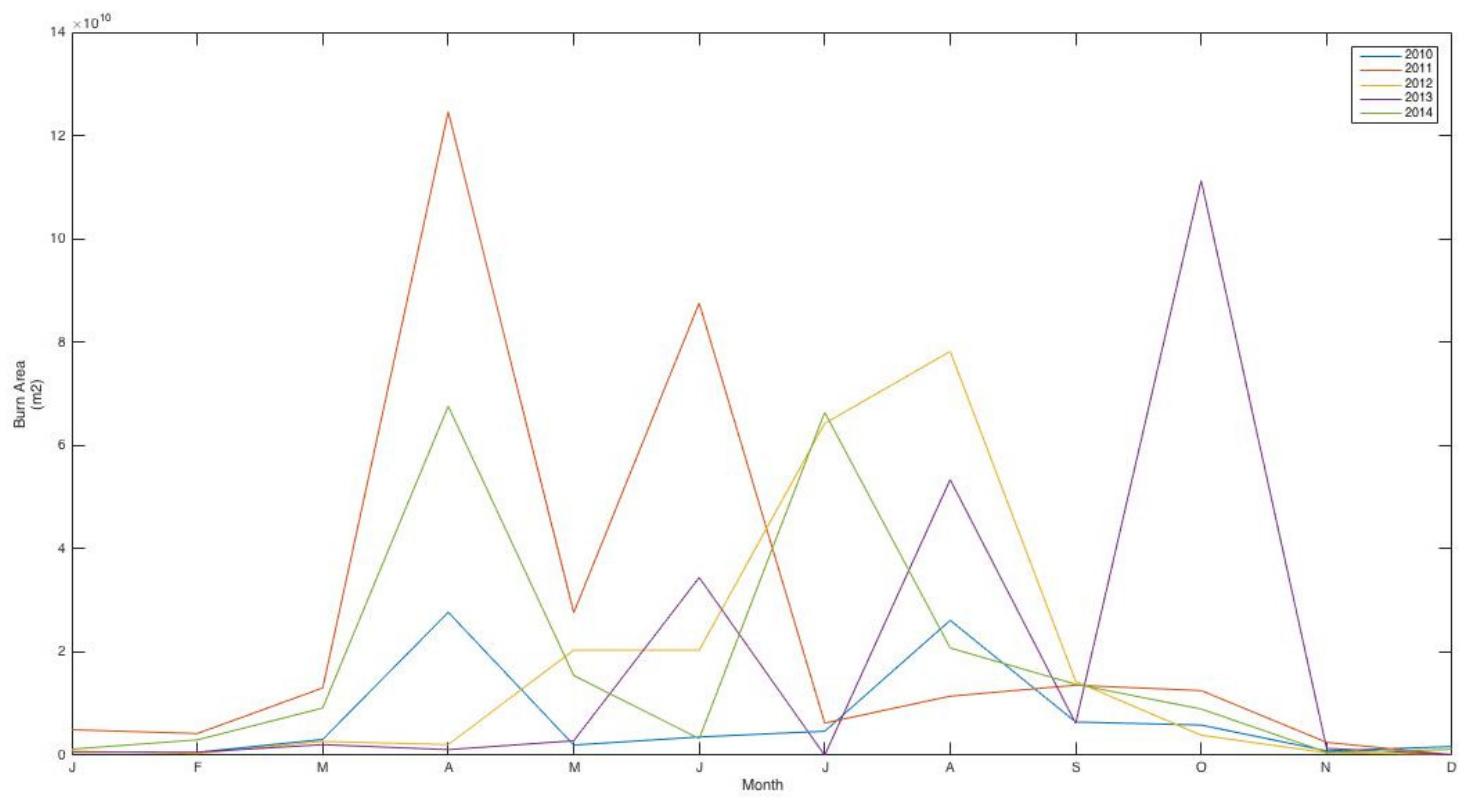

Figure 10. The monthly total burn area $\left(\mathrm{m}^{2}\right)$ for each year in the study. The monthly total burn area for 2010 is represented by the blue line, the total burn area for 2011 is represented by the red line, the total burn area for 2012 is represented by the gold line, the total burn area for 2013 is represented by the purple line and the fires in 2014 is represented by the green line.

Both April and August saw the highest total burn areas $\left(\sim 2 \mathrm{E} 10 \mathrm{~m}^{2}\right)$ in 2010. The peak total burn area in $2011\left(1.2 \mathrm{E} 11 \mathrm{~m}^{2}\right)$ occurred in April, with a secondary peak occurring in July $\left(8.7 \mathrm{E} 10 \mathrm{~m}^{2}\right)$. However, in 2012, the peak burn area $\left(7.8 \mathrm{E} 10 \mathrm{~m}^{2}\right)$ occurred in August, with a secondary peak (2.0E10 $\mathrm{m}^{2}$ ) occurring in May. In 2013, there were three major peaks in burn area. The smallest peak (3.4E10 $\left.\mathrm{m}^{2}\right)$ occurred in July, the middle peak $\left(5.3 \mathrm{E} 10 \mathrm{~m}^{2}\right)$ occurred in August and then the largest peak $\left(1.1 \mathrm{E} 11 \mathrm{~m}^{2}\right)$ occurred in October. Finally, in 2014, there were two major peaks $\left(6.6 \mathrm{E} 10\right.$ and $\left.2.1 \mathrm{E} 10 \mathrm{~m}^{2}\right)$ that occurred in July and August, respectively.

\subsection{Ammonia Emissions from Biomass Burning}

Based on the trends in the recent national fire number, one would expect ammonia emissions from fires to decrease. However, the trend in annual ammonia emissions from fires is actually positive (Figure 11). The lowest $\mathrm{NH}_{3}$ emissions from fires were observed in 2010 (10000 tons), while the highest $\mathrm{NH}_{3}$ emissions from were observed in 2011 (110000 tons).

Ammonia emissions in 2013 were approximately 494687 tons, while the emissions in 2013 and 2014 were approximately 470793 tons and 873373 tons, respectively. This overall increase in ammonia emissions is likely due to two key factors: the increase in the total burn area and the decrease in the fire radiative power. Because ammonia is emitted during the smoldering stage, a larger burn area and a lower fire radiative power are favorable. This is evident in Figures 12 and 13, which show that emissions increase proportionally with burn area and fire number and that emissions are higher at lower FRP values, respectively. 
The 1st International Electronic Conference on Atmospheric Sciences (ECAS 2016), 16-31 July 2016;

Sciforum Electronic Conference Series, Vol. 1, 2016

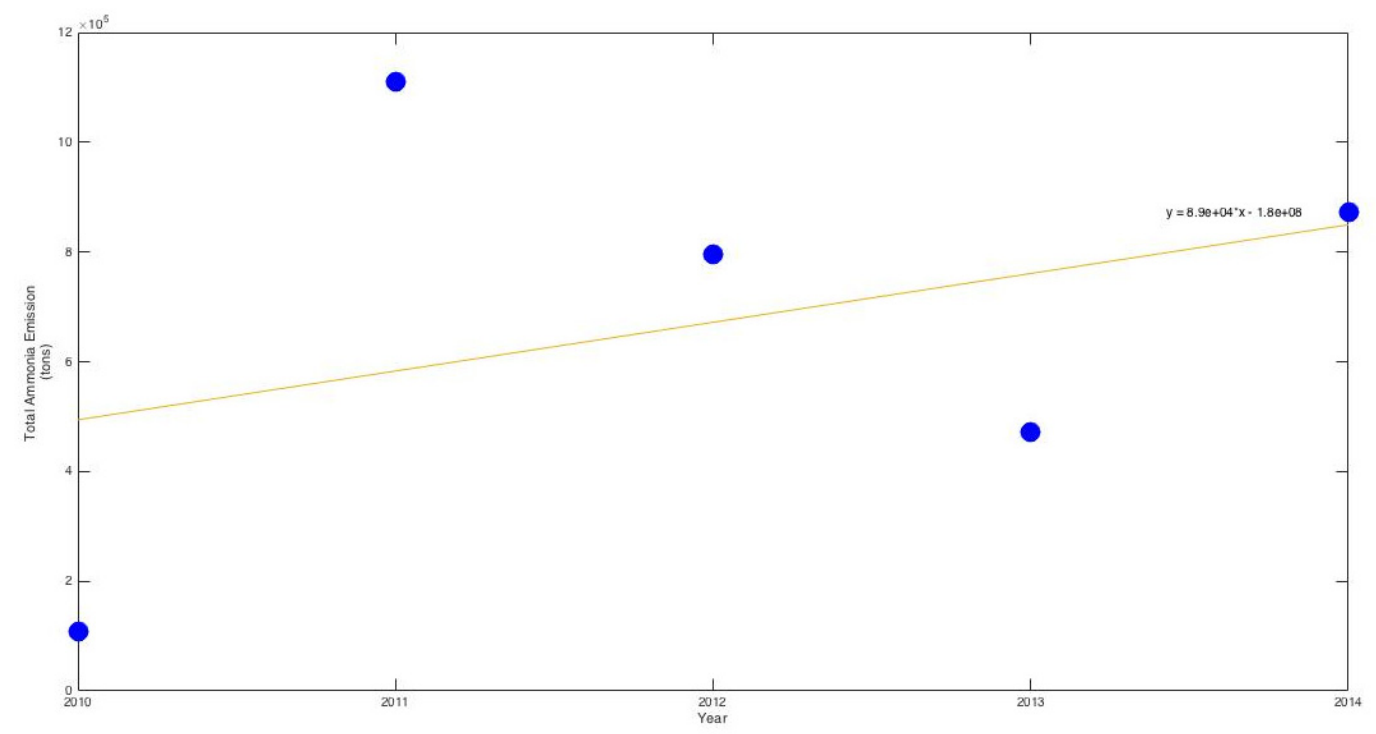

Figure 11. The calculated total yearly ammonia emissions (tons) represented by blue dots. The associated trend line is displayed as a gold line with the linear equation represented in black.

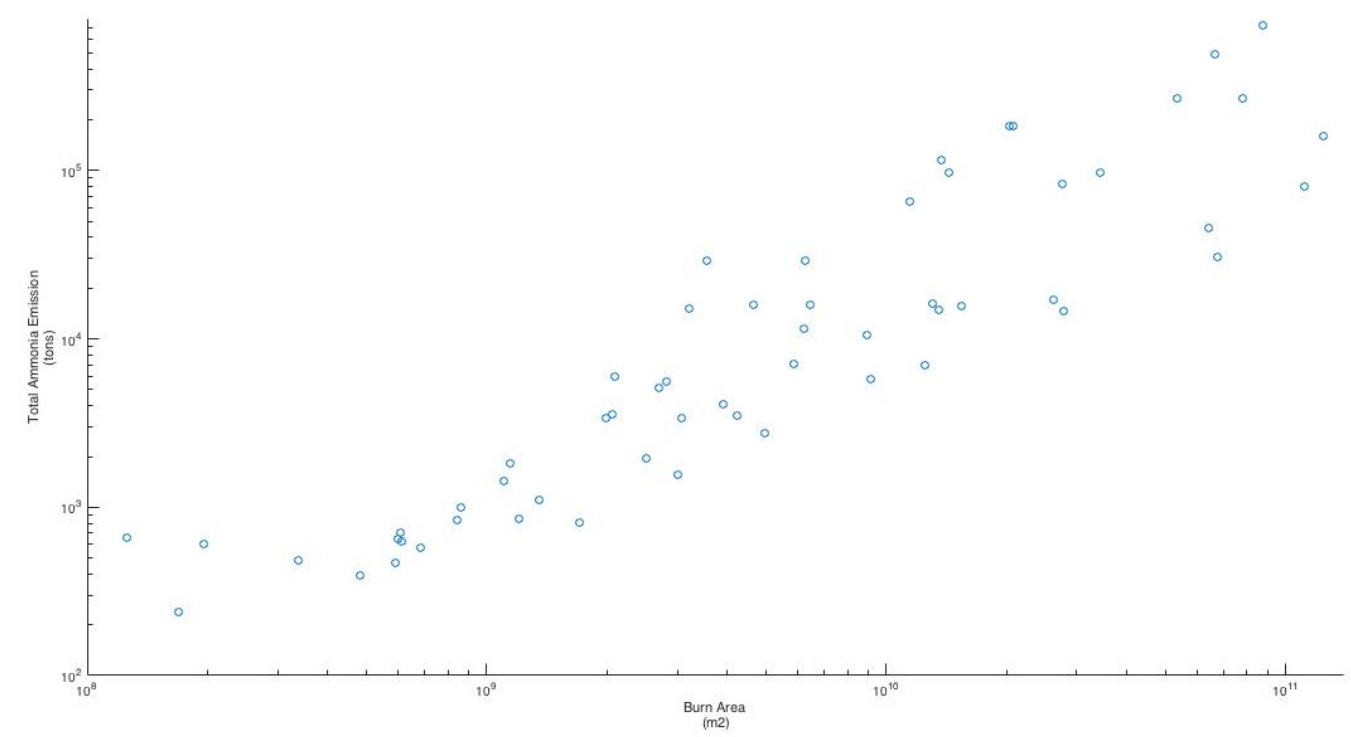

Figure 12. Comparing the total monthly ammonia emissions (tons) from fires, represented by the blue circles, with the total monthly burn area $\left(\mathrm{m}^{2}\right)$ for the continental United States, plotted on a logarithmic scale. 
The 1st International Electronic Conference on Atmospheric Sciences (ECAS 2016), 16-31 July 2016; Sciforum Electronic Conference Series, Vol. 1, 2016

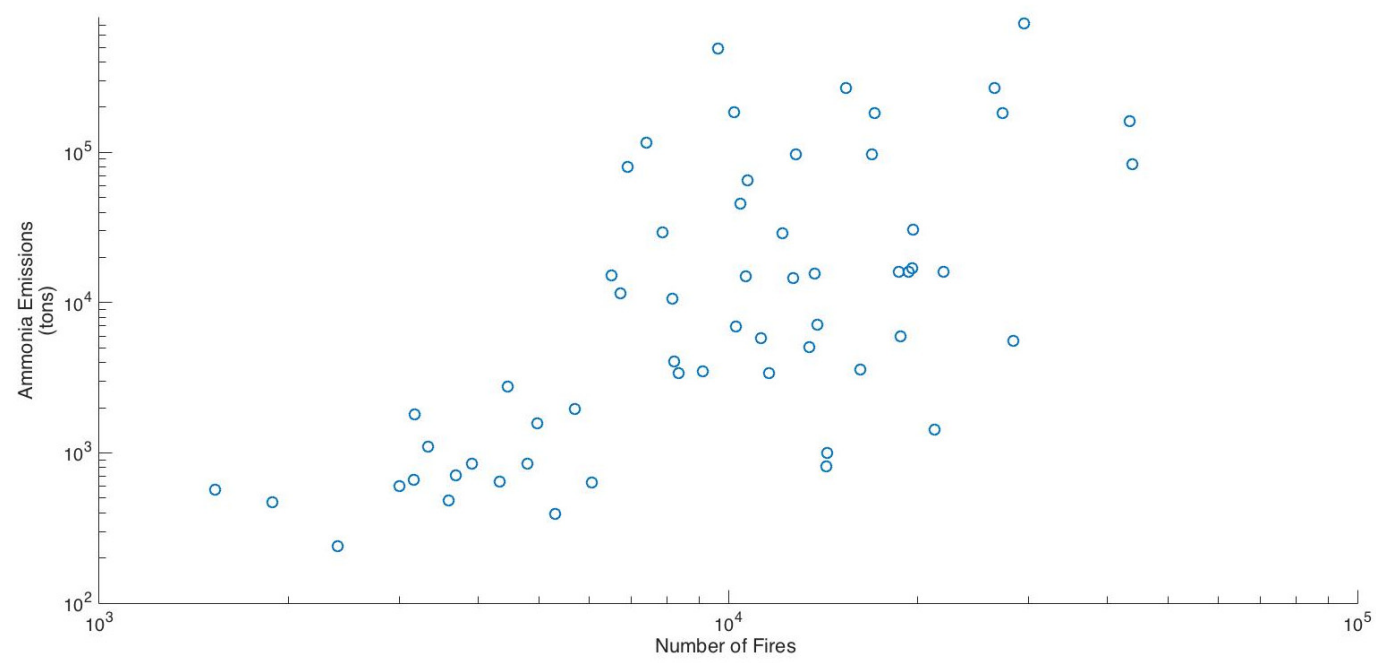

Figure 13. Comparing the total monthly ammonia emissions (tons) from fires, represented by the blue circles, with the total monthly number of fires for the entire continental United States, plotted on a logarithmic scale.

While the trend from the comparison of the number of fires and ammonia emissions from fires is not nearly as linear $\left(R^{2}=0.15\right)$ as is observed comparing the ammonia emissions from fires with the burn area $\left(R^{2}=0.41\right)$, the trend is still clearly positive. On a monthly scale, the trend in the ammonia emissions change such that the peak occurs later in the year (July-September) as oppose to April-June (Figure 14). In 2010 and 2011, the peak $\mathrm{NH}_{3}$ emissions occurred in June (28999 tons and 725754 tons, respectively), with secondary peaks occurring during April (14519 tons and 160362 tons, respectively). Peak $\mathrm{NH}_{3}$ emissions occurred in August (267602 tons and 268999 tons) during 2012 and 2013, respectively, and in July (491159 tons) during 2014.

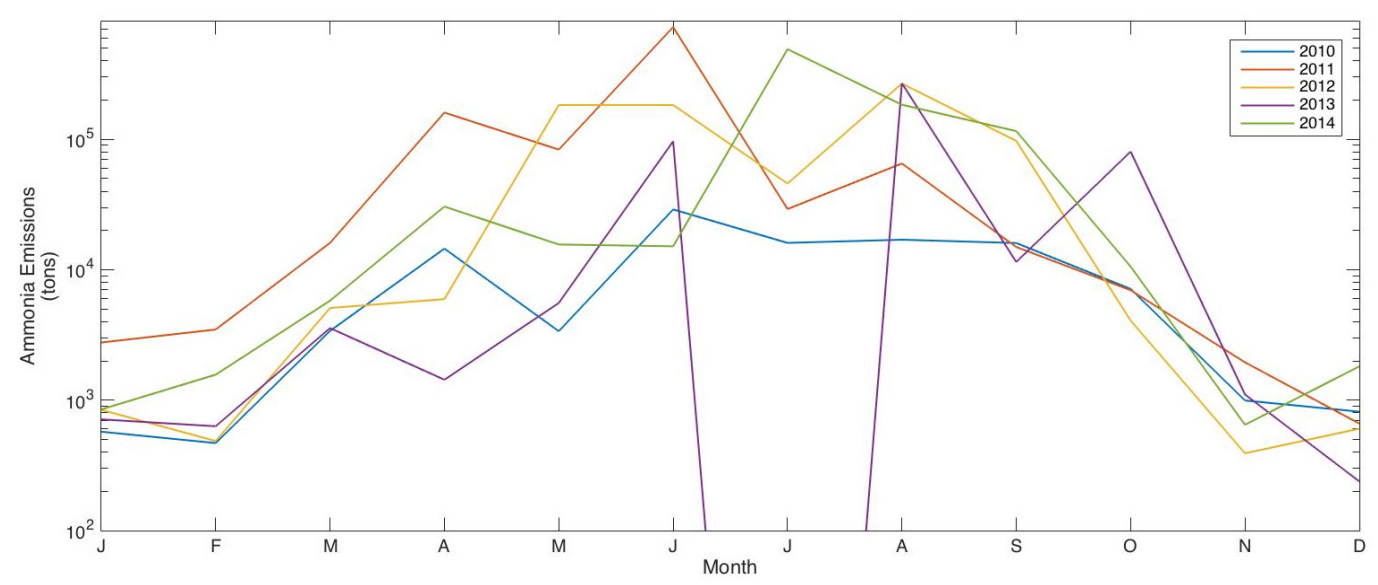

Figure 14. The monthly total ammonia emissions from fires (tons) for each year in the study. The monthly total ammonia emissions from fires for 2010 is represented by the blue line, the ammonia emissions for 2011 is represented by the red line, the ammonia emissions for 2012 is represented by the gold line, the ammonia emissions for 2013 is represented by the purple line and the ammonia emissions in 2014 is represented by the green line. Note that the ammonia emissions are plotted on a logarithmic scale.

Based on this monthly comparison, the general trend appears to shift slightly such that the peak ammonia emissions from fires changes from occurring in late spring/early summer to the peak 
The 1st International Electronic Conference on Atmospheric Sciences (ECAS 2016), 16-31 July 2016;

Sciforum Electronic Conference Series, Vol. 1, 2016

occurring in late summer, with a secondary peak occurring in the fall of 2014. This suggests that the fire season is expanding, which is likely a result of drier conditions in the western United States.

\subsection{Comparing Calculated Emissions with the US EPA NEI}

On a national scale, the calculated ammonia emissions from biomass burning were found to be, on average, a factor of 0.49 higher than the US EPA National Emissions Inventory, with the exception of 2010 (Figure 15).

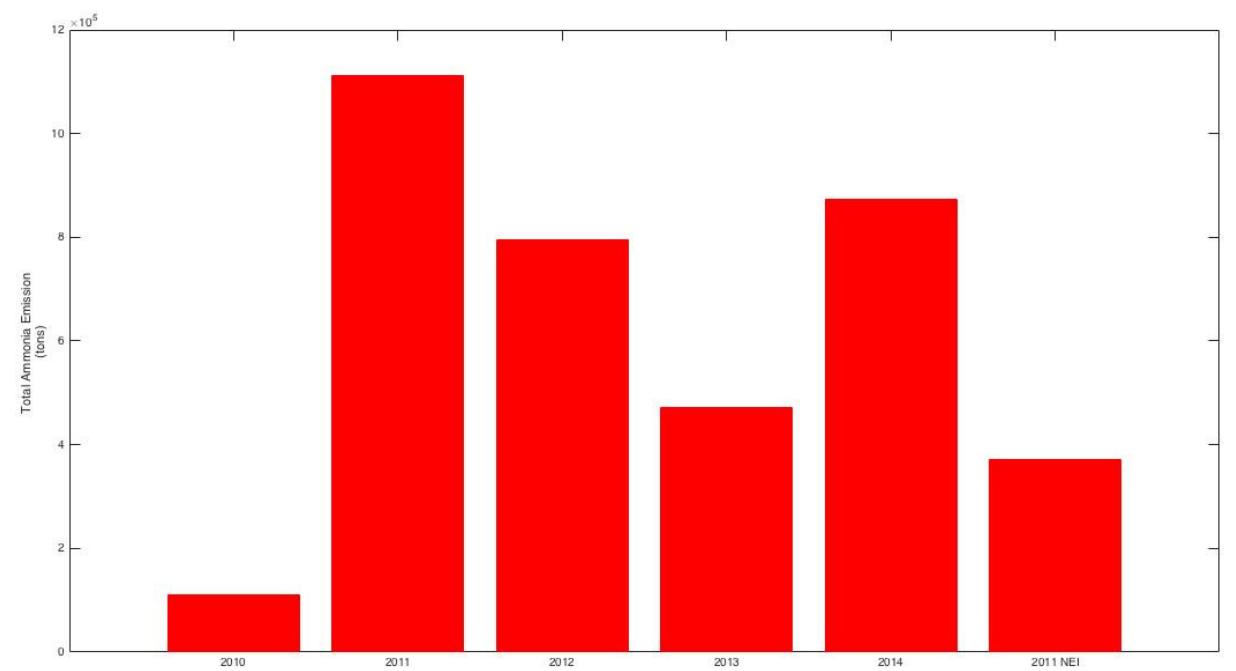

Figure 15. Comparing yearly total ammonia emissions from fires for the continental US with the 2011 US EPA National Emissions Inventory for continental US ammonia emissions from fires. The first five red bars represent the calculated yearly ammonia emissions from fires while the last red bar represents the 2011 US EPA NEI value for ammonia emissions for fires.

The total calculated ammonia emissions in 2010 (109426 tons) were a factor of 2.40 lower than the 2011 National Emission Inventory. However, the US EPA NEI for $\mathrm{NH}_{3}$ emissions from fires is actually lower than the observed yearly total national emissions for 2011-2014. In 2011, the NEI was found to be a factor of 0.66 lower than the calculated $\mathrm{NH}_{3}$ emissions from fires (1110854 tons). Similarly, the calculated emissions of $\mathrm{NH}_{3}$ from fires in 2012 (794833 tons) were a factor of 0.53 than the US EPA NEI. The US EPA inventory was slightly closer to the national calculated emissions of $\mathrm{NH}_{3}$ in 2013 (470942 tons), with the inventory being lower by a factor of 0.21 . However, the US EPA NEI for fire emissions of ammonia was found to be a factor of 0.57 lower than what was calculated (873681 tons). This suggests that on a national scale, the US EPA National Emissions Inventory under predicts ammonia emission from biomass burning.

\subsection{Dependence upon Meteorology}

Because fires, and thus $\mathrm{NH}_{3}$ emissions from fires, are so dependent upon the meteorology, it is necessary to examine the relationship between the meteorological conditions (precipitation, temperature) and the fire frequency, strength, as well as the $\mathrm{NH}_{3}$ emissions from biomass burning. Figure 16 shows the relationship between precipitation and ammonia emissions while Figure 17 shows the relationship between precipitation and the number of fires on a monthly basis. 
The 1st International Electronic Conference on Atmospheric Sciences (ECAS 2016), 16-31 July 2016; Sciforum Electronic Conference Series, Vol. 1, 2016

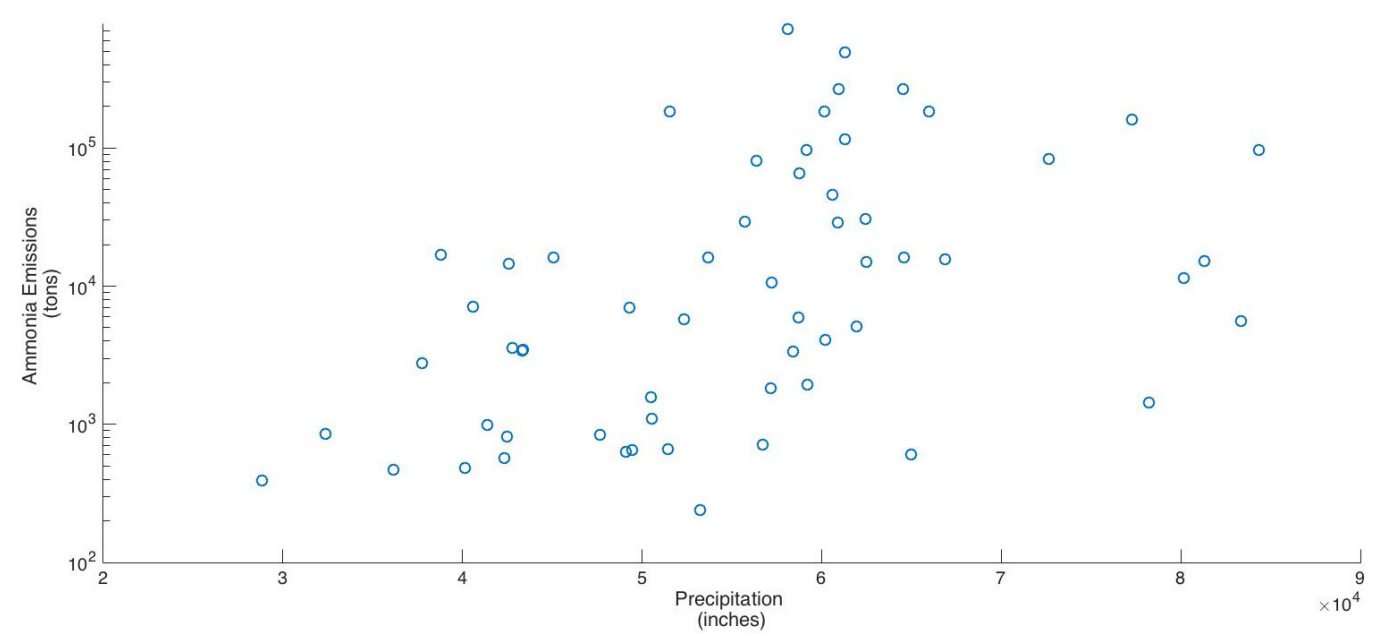

Figure 16. Comparing the total monthly ammonia emissions (tons) from fires, represented by the blue circles, with the total monthly precipitation (inches) for the entire continental United States. Note the ammonia emissions from fires plotted on a logarithmic scale.

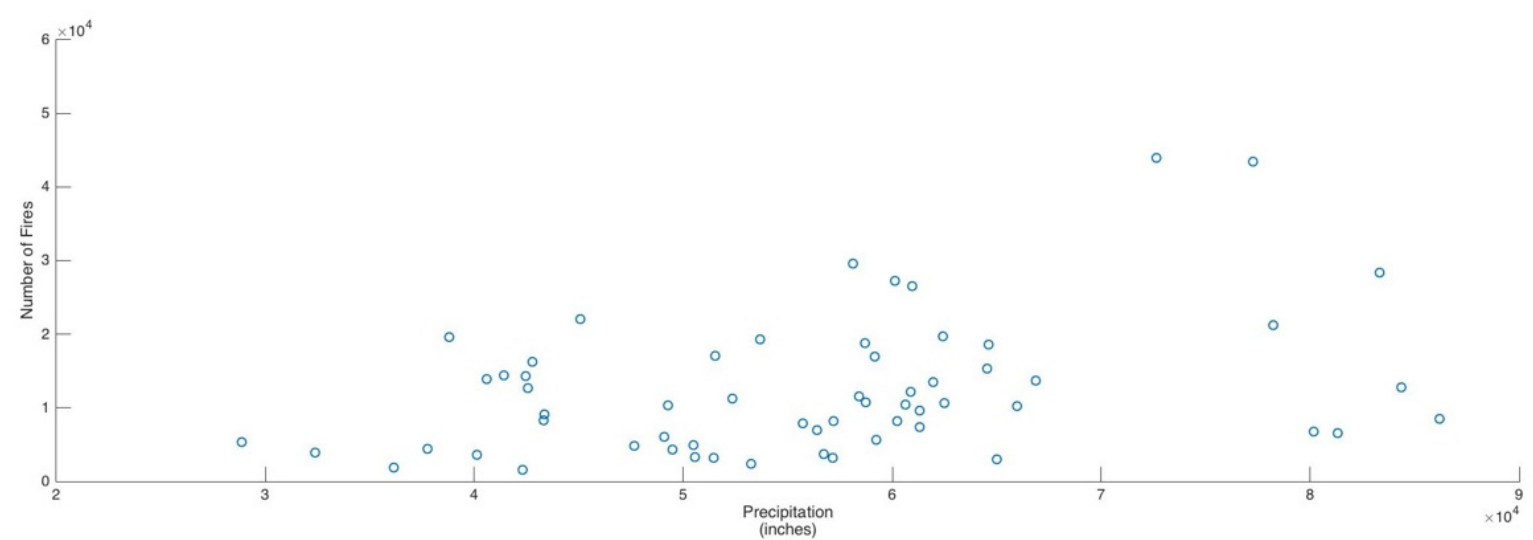

Figure 17. Comparing the total number of fires, represented by the blue circles, with the total monthly precipitation (inches) for the entire continental United States.

While one would expect $\mathrm{NH}_{3}$ emissions and the number of fires to decrease with increased precipitation, the peak monthly $\mathrm{NH}_{3}$ emissions and peak fire numbers actually occurred between $50,000-80,000$ inches of precipitation. When comparing the monthly fire radiative power with the monthly precipitation, the highest FRP values were observed at precipitation values of 40,000-50,000 inches, nationally (Figure 18). However, apart from this, the average FRP remains fairly consistent with values between 50 and $90 \mathrm{MW}$ at all amounts of precipitation. 
The 1st International Electronic Conference on Atmospheric Sciences (ECAS 2016), 16-31 July 2016; Sciforum Electronic Conference Series, Vol. 1, 2016

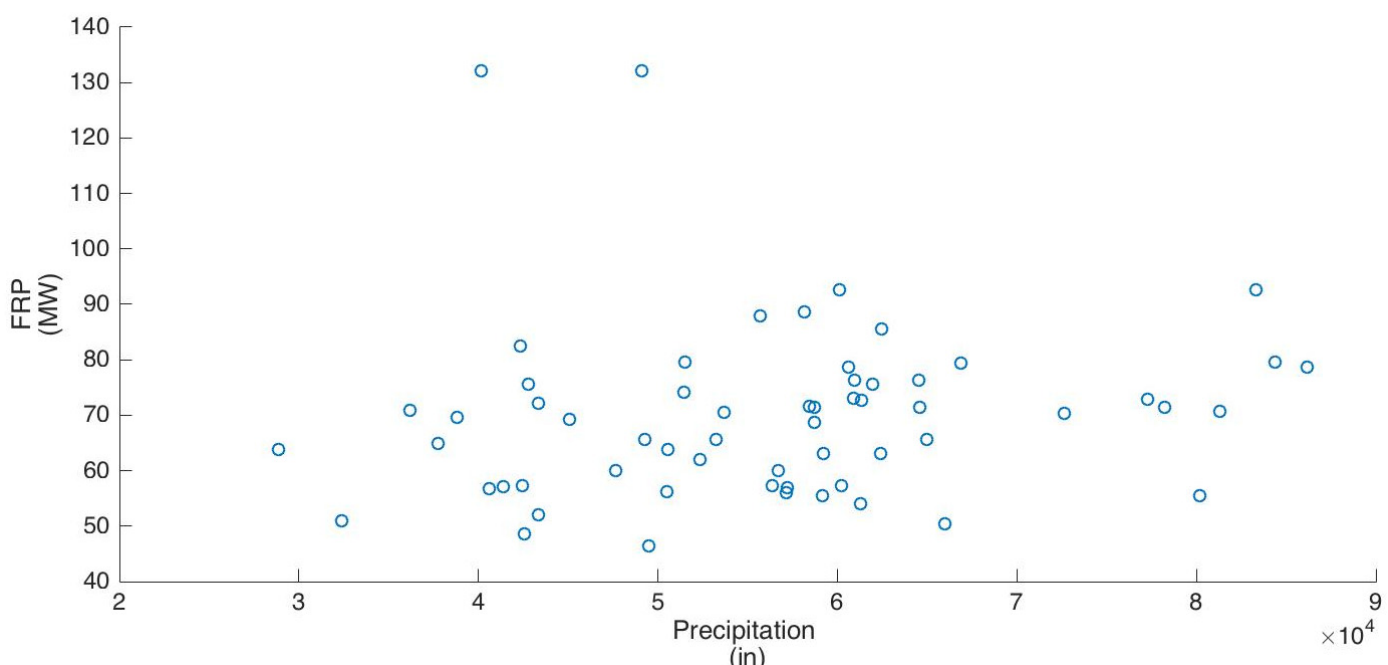

(in)

Figure 18. Comparing the fire radiative power (MW), represented by the blue circles, with the total monthly precipitation (inches) for the entire continental United States.

In addition to precipitation, temperature is also a very important element in fires. When comparing the average monthly temperature with the monthly fire number, it is evident that fire number tends to increase with increasing temperature (Figure 19).

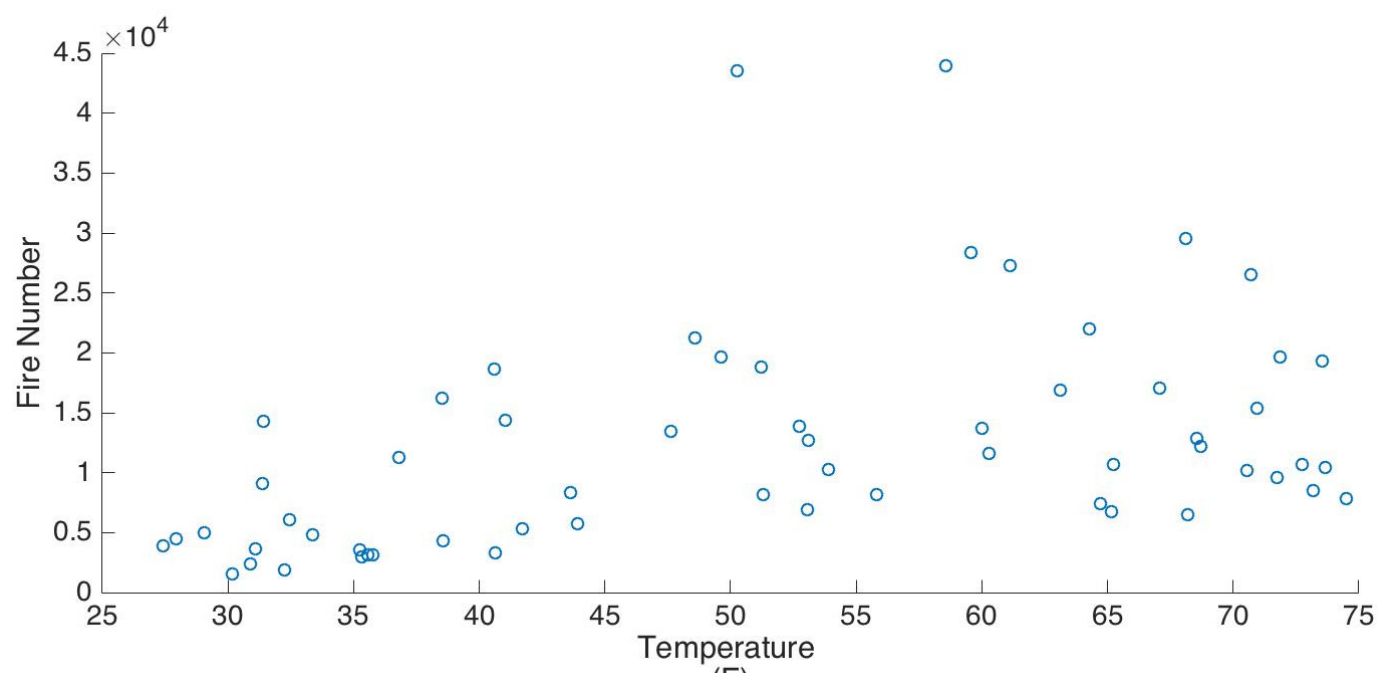

(F)

Figure 19. Comparing the fire number, represented by the blue circles, with the average monthly temperature $\left({ }^{\circ} \mathrm{F}\right)$ for the entire continental United States.

However, the maximum monthly fire numbers occur at average monthly temperature between $50^{\circ} \mathrm{F}$ and $60^{\circ} \mathrm{F}$. In contrast to this, $\mathrm{NH}_{3}$ emissions from fires have a directly proportional relationship with temperature, where emissions increase with increasing temperature (Figure 20). This is slightly different from the relationship found between the number of fires and the monthly average temperature because ammonia emissions are more dependent upon temperature. When comparing the average monthly FRP with the average monthly temperature (Figure 21), very high FRP values $(130 \mathrm{MW})$ occurred at low average monthly temperature $\left(30^{\circ} \mathrm{F}-40^{\circ} \mathrm{F}\right)$.

Higher FRP values (85-90 MW) occurred at higher temperatures $\left(60^{\circ} \mathrm{F}-75^{\circ} \mathrm{F}\right)$, however, FRP values of $50-80 \mathrm{MW}$ occurred steadily across all temperatures. Based on this analysis, is appears that the most important meteorological parameter for $\mathrm{NH}_{3}$ emissions from fires is temperature. 
The 1st International Electronic Conference on Atmospheric Sciences (ECAS 2016), 16-31 July 2016; Sciforum Electronic Conference Series, Vol. 1, 2016

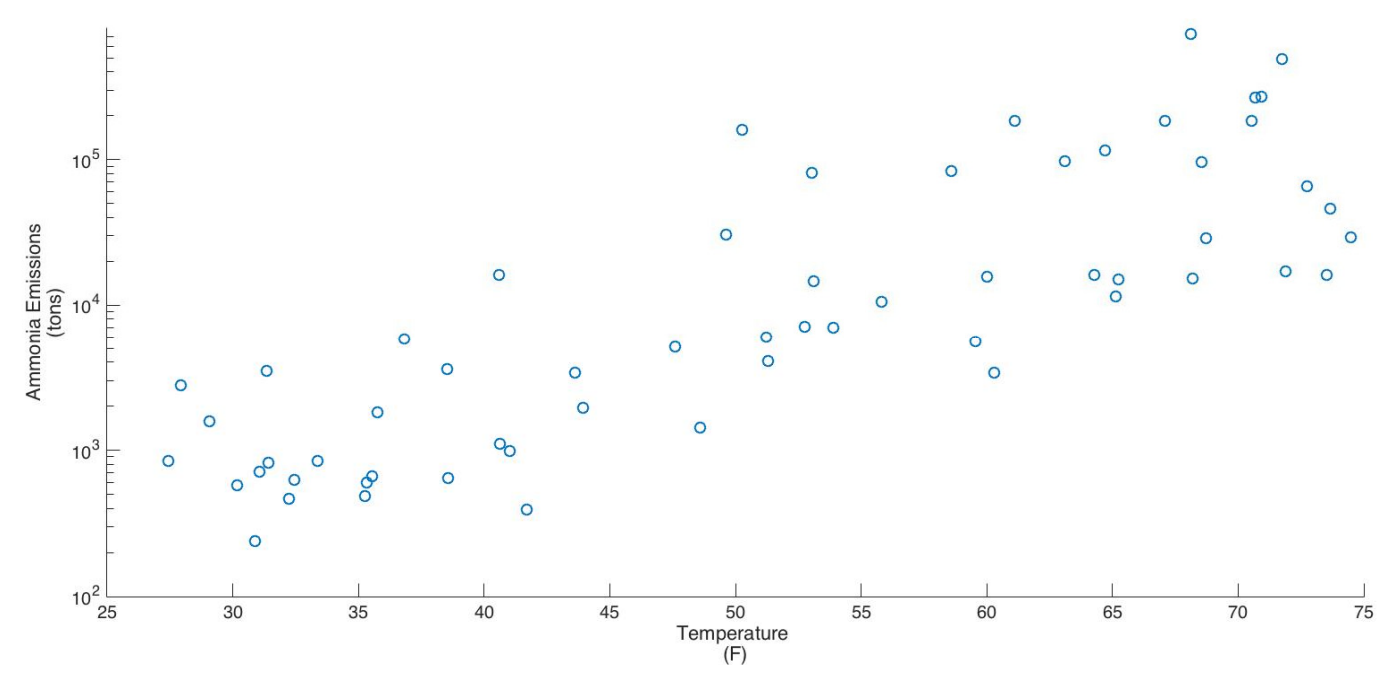

Figure 20. Comparing the total monthly ammonia emissions (tons) from fires, represented by the blue circles, with the average monthly temperature $\left({ }^{\circ} \mathrm{F}\right)$ for the entire continental United States. Note the ammonia emissions from fires plotted on a logarithmic scale.

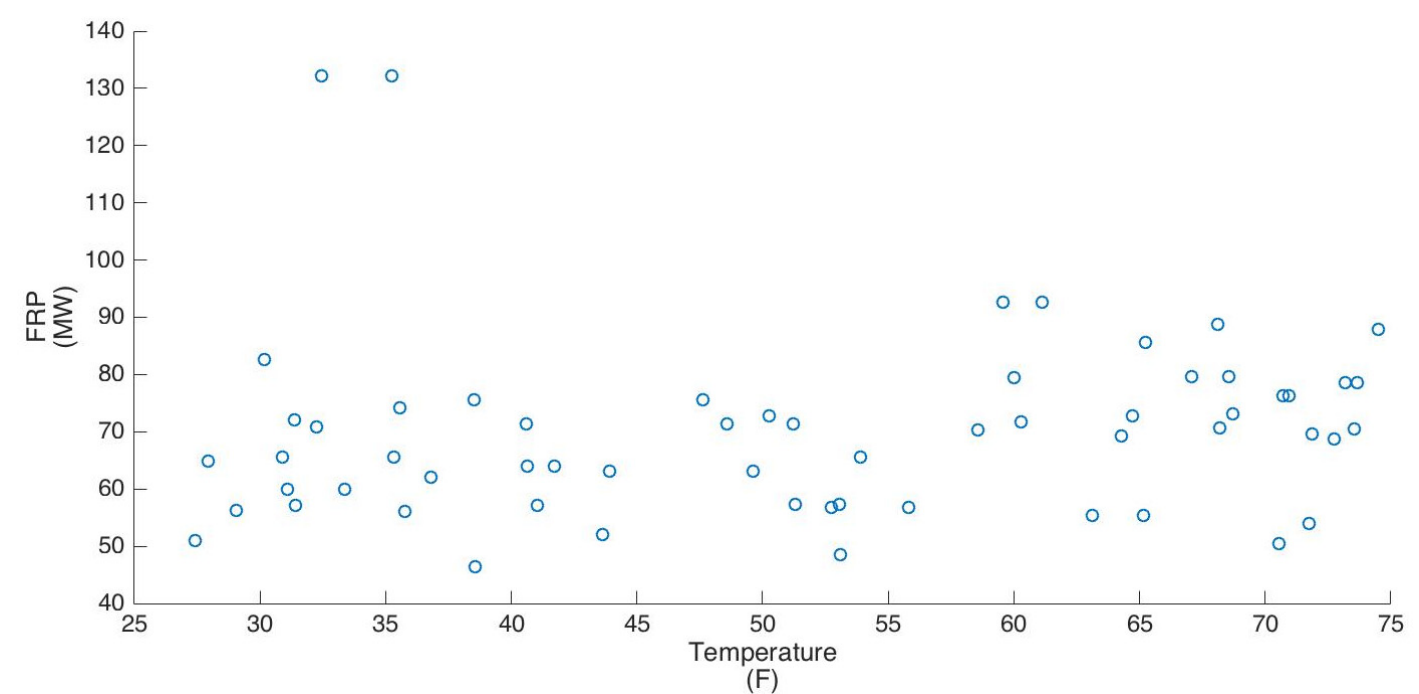

Figure 21. Comparing the average monthly fire radiative power (MW), represented by the blue circles, with the average monthly temperature $\left({ }^{\circ} \mathrm{F}\right)$ for the entire continental United States.

\section{Discussion}

As discussed in Section 3.1, ambient $\mathrm{NH}_{3}$ concentrations from both satellite and in-situ measurements show a very slight increase across the US from 2010-2014. This is in accordance with [48], who measured in-situ measurements of $\mathrm{NH}_{3}$ across the central and eastern US from 2008-2014. Similarly, [25] saw an increase in gaseous ammonia concentrations across the southeastern US from 2004-2014. [25] attributed this increase in gaseous ammonia concentrations to an increase in wildfires across the southeast. While it isn't possible to deduce the exact cause of this marginal increase in ammonia concentrations across the CONUS, two potential sources are the changes in fires and changes in agricultural practices as the demand for feed, fiber and fuel increase with the increasing population. Despite the fact that the overall trend in the number of fires per year and the average annual fire radiative power per year is decreasing, the total yearly burn area increased. This suggests that fires became spatially larger and were able to persist for longer periods of time in the smoldering phase. Because $\mathrm{NH}_{3}$ is emitted into the atmosphere during the smoldering phase, which occurs at 
The 1st International Electronic Conference on Atmospheric Sciences (ECAS 2016), 16-31 July 2016;

Sciforum Electronic Conference Series, Vol. 1, 2016

low FRPs, this would suggest an increase in $\mathrm{NH}_{3}$ emissions from fires over the period of interest. When calculating the $\mathrm{NH}_{3}$ emissions from biomass burning across the CONUS, this increasing trend was evident.

On a monthly scale, the yearly emissions of $\mathrm{NH}_{3}$ from fires show that the trend in the peak monthly emission shifts from late spring/early summer to late summer. The peak number of fires occurred in the spring during the majority of the fire period (peak fire count in 2010 occurred in the late summer/early fall). This trend is likely due to agricultural burning, which tends to happen the early winter/early spring [49]. The average monthly FRP remained fairly constant, ranging between 60 and $90 \mathrm{MW}$ from January to October. However, it is evident that the monthly FRP values are consistently lower in 2013 and 2014 than in the prior years. In contrast to this, the peak in the monthly total burn area from 2010 to 2014 shifted from occurring in the spring to occurring in the fall. The monthly trends in fire strength and activity is in accordance with the trends in the monthly $\mathrm{NH}_{3}$ emissions from biomass burning. The larger burn area and lower FRP created favorable conditions for NH3 emission.

Nationally, the average yearly temperature has actually decreased while the yearly precipitation totals have increased from 2010 to 2014. Considering the severe drought that occurred during this period in the western US, this was surprising. When comparing the monthly total number of fires with the monthly total precipitation on a national scale, the highest number of monthly fires actually occurred during a month with a great amount of precipitation. In contrast to this, the monthly average FRP stayed fairly constant within a range of 50 to $90 \mathrm{MW}$ across all amounts of precipitation, however the highest monthly FRP values were observed at relatively lower precipitation values. While this could be attributed to the fires and precipitation potentially not aligning in time and space, this could also suggest that precipitation does not play a major role in the FRP of a fire, except at very high FRP values. Similar results were found when the monthly total $\mathrm{NH}_{3}$ emissions from fires were compared with the monthly total precipitation, where the higher monthly emissions occurring at higher amounts of precipitation. Since this study is on a national scale, it is possible that these fires, and thus $\mathrm{NH}_{3}$ emissions, did not occur where the precipitation occurred. In addition to this, another possible explanation would be if the precipitation was not very heavy, it could either have no impact on a fire or reduce the fire to the smoldering stage, which is conducive for $\mathrm{NH} 3$ emissions.

When evaluating temperature with fire number, it was found that fire number and $\mathrm{NH}_{3}$ emissions from fire increase with increasing temperature, with the exception of two months with large fires occurring at average monthly temperatures of around $55^{\circ} \mathrm{F}$. Because fire number and $\mathrm{NH}_{3}$ emissions from fires (and agriculture, for that matter) are generally greatest from spring to fall, this relationship is expected. In addition to this, the peak in the monthly total fire number occurring around $55^{\circ} \mathrm{F}$ can likely be attributed to several agricultural burns occurring in the late winter in southern states. As was found when comparing the average FRP with total precipitation, in the monthly average FRP remains fairly constant with increasing average temperature. However, extremely high values of FRP occurred at low temperatures. These high values may also be attributed to agricultural burns occurring in late winter/early spring. Based on these results, it appears that temperature is the most important meteorological parameter for fire frequency and emissions of $\mathrm{NH}_{3}$, while the FRP does not appear to be too dependent upon either parameter.

Future directions for this work include expanding the period of interest from 2004 to 2014 and breaking the study area down by EPA region in order to see how concentrations of $\mathrm{NH}_{3}$, fire strength and frequency, and fire emissions change on a per region basis. In addition to this, $\mathrm{NH}_{3}$ emission estimates will also be derived using a top down method similar to [50], on a regional and national scale. The results of each region will be compared with the US EPA NEI to see how each region differs with respect to the calculated yearly $\mathrm{NH}_{3}$ emissions from fires and to determine where the inventory is most accurate and where it is least accurate in order to help determine where potential errors lie. Finally, a statistical regression model that will be used to project ammonia emissions using a combination of both biological and meteorological components will be developed and compared against other emission calculation techniques. 
The 1st International Electronic Conference on Atmospheric Sciences (ECAS 2016), 16-31 July 2016;

Sciforum Electronic Conference Series, Vol. 1, 2016

\section{Conclusions}

Currently, $\mathrm{NH}_{3}$ emissions from fires account for approximately $8 \%$ of all $\mathrm{NH}_{3}$ emissions in the continental United States. As the climate continues to change, $\mathrm{NH}_{3}$ emissions from fires, particularly in the southwestern and western US, will likely increase. In this preliminary analysis, $\mathrm{NH}_{3}$ total concentrations appear to have been gradually increasing on a national scale from 2010 to 2014 . However, the total fire number and fire radiative power has, on average, decreased during the period. The total burn area per year has increased through this time, which suggests that fires are increasing in size, but decreasing in power. Because $\mathrm{NH}_{3}$ is emitted during the smoldering stage of fires, which is associated with lower fire radiative powers, this change in fire activity allows for a larger spatial area to burn at a lower FRPs, conditions which are favorable to $\mathrm{NH}_{3}$ emissions. The total emission of ammonia from fires, on a national scale, has increased, which was expected based on the changes in fire activity. When comparing the US EPA National Emissions Inventory for $\mathrm{NH}_{3}$ emissions from fires for the continental United States, it was found that the NEI was approximately a factor of 0.49 lower than what was calculated. While the inventory was higher than the calculated $\mathrm{NH}_{3}$ emissions for 2010, it was much lower than what was calculated for 2011-2014. Therefore, based on this, it can be concluded that the US EPA NEI for ammonia emissions from fires, on average, under predicts concentrations of $\mathrm{NH}_{3}$ on a national scale.

Acknowledgments: We thank our Air Quality Research Group; the NOAA National Air Quality Forecasting Program; the US EPA Atmospheric Modeling and Analysis Division; and the MEAS Department for the support provided.

Author Contributions: Casey Bray gathered much of the data, performed the calculations, analyzed the data and wrote the report. William Battye provided and helped interpret the TES data. Viney Aneja supervised the research and assisted with questions. Daniel Tong, Pius Lee and Youhua Tang helped develop the methodology used in this report and assisted in the review process.

Conflicts of Interest: The authors declare no conflict of interest.

\section{Abbreviations}

AMoN: Ammonia Monitoring Network

AVHRR: Advanced Very High Resolution Radiometer

CONUS: Continental United States

EPA: Environmental Protection Agency

FIRMS: Fire Information for Resource Management System

FRP: Fire Radiative Power

GHCND: Global Historical Climatology Network

MODIS: Moderate Resolution Imaging Spectroradiometer

NADP: National Atmospheric Deposition Program

NASA: National Aeronautics and Space Administration

NEI: National Emissions Inventory

NH3: Ammonia

NOAA: National Oceanic and Atmospheric Administration

PM2.5: Fine Particulate Matter

US: United States

TES: Tropospheric Emission Spectrometer 
The 1st International Electronic Conference on Atmospheric Sciences (ECAS 2016), 16-31 July 2016; Sciforum Electronic Conference Series, Vol. 1, 2016

\section{References}

1. Robarge, W.P.; Walker, J.T.; McCulloch, R.B.; Murray, G. Atmospheric concentrations of ammonia and ammonium at an agriculture site in the southeast United States. Atmos. Environ. 2002, 36, 1661-1674.

2. Baek, B.H.; Aneja, V.P. Measurement and analysis of the relationship between ammonia, acid gases, and fine particles in Eastern North Carolina. J. Air Waste Man. Assoc. 2004, 54, 623-633.

3. Baek, B.H.;Aneja, V.P.;Tong. Q. Chemical coupling between ammonia, acid gases, and fine particles. J. Environ. Poll. 2004, 129, 89-98.

4. Day, D.E.; Chen, X.; Gebhart, K.A.; Carrico, C.M.; Schwandner, F.M.; Benedict, K.B.; Schichtel, B.A.; Collett, J.L. Spatial and temporal variability of ammonia and other inorganic aerosol species. Atmos. Environ. 2012, 61, 490-498.

5. Chen, X.; Day, D.; Schichtel, B.; Malm, W.; Matzoll, A.K.; Mojica, J.; McDade, C.E.; Hardison, E.D.; Hardison, D.L.; Walters, S; Van De Water, M. Seasonal ambient ammonia and ammonium concentrations in a pilot IMPROVE NHx monitoring network in the western United States. Atmos. Environ. 2014, 91, 118-126.

6. Pope III, C.; Ezzati, M.; Dockery, D.W. Fine-particulate air pollution and life expectancy in the united states N. Engl. J. Med. 2009, 360, 376-386.

7. Behera, S.N.; Sharma, M. Investigating the potential role of ammonia in ion chemistry of fine particulate matter formation for an urban environment. Sci. Total Environ. 2010, 408, 3569-3575.

8. Behera, S.N.; Sharma, M. Reconstructing Primary and Secondary Components of PM 2.5 Composition for an Urban Atmosphere. Aerosol Sci. Tech. 2010, 44, 983-992.

9. Heald, C.L.; Jr., J.L.C.; Lee, T.; Benedict, K.B.; Schwandner, F.M.; Li, Y.; Clarisse, L.; Hurtmans, D.R.; Damme, M.V.; Clerbaux, C.; Coheur, P.-F.; Philip, S.; Martin, R.V.; Pye, H.O.T. Atmospheric ammonia and particulate inorganic nitrogen over the United States. Atm. Chem. Phys. 2012, 12, 10295-10312.

10. Fan, J. Simulations of fine particulate matter (PM 2.5) in Houston, Texas. J. Geophys. Res. 2005, 110.

11. Pinder, R.W.; Gilliland, A.B.; Dennis, R.L. Environmental impact of atmospheric NH 3 emissions under present and future conditions in the eastern United States. Geophys. Res. Lett. Lett. 2008, 35, doi:10.1029/2008GL033732.

12. Simpson, D.; Andersson, C.; Christensen, J.; Engardt, M.; Geels, C.; Nyiri, A.; Posch, M.; Soares, J.; Sofiev, M.; Wind, P.; et al. Impacts of climate and emission changes on nitrogen deposition in Europe: A multi-model study. Atmos. Chem. Phys. 2014, 14, 6995-7017.

13. Langford, A.O.; Fehsenfeld, F.C.; Zachariassen, J.; Schimel, D.S.Gaseous ammonia fluxes and background concentrations in terrestrial ecosystems of the United States. Glob. Biogeochem. Cycles 1992, 6, 459-483.

14. Kapoor, R.; Singh, G.; Tiwari, S. Ammonia concentration vis-a-vis meteorological conditions at Delhi, India. Atmos. Res. 1992, 28, 1-9.

15. Schlesinger, W.; Hartley, A. A global budget for atmospheric NH3. Biogeochem. 1992, 15.

16. Flechard, C.; Fowler, D. Atmospheric ammonia at a moorland site. I: The meteorological control of ambient ammonia concentrations and the influence of local sources. Q. J. R. Meterol.. Soc. 1998, 124, 733-757

17. Battye, W. Evaluation and improvement of ammonia emissions inventories. Atmos. Environ. 2003, 37, 3873-3883.

18. US EPA National Emissions Inventory 2011. Available online: http://www3.epa.gov/ttnchie1/net/ 2011inventory.html (accessed on 10 June 2016)

19. Alves, C.A.; Vicente, A.; Monteiro, C.; Gonçalves, C.; Evtyugina, M.; Pio, C. Emission of trace gases and organic components in smoke particles from a wildfire in a mixed-evergreen forest in Portugal. Sci. Total Environ. 2011, 409, 1466-1475.

20. Nance, J.D.; Hobbs, P.V.; Radke, L.F.; Ward, D.E. Airborne measurements of gases and particles from an Alaskan wildfire. J. Geophys. Res. 1993, 98, 14873.

21. Goode, J.G.; Yokelson, R.J.; Ward, D.E.; Susott, R.A.; Babbitt, R.E.; Davies, M.A.; Hao, W.M.Measurements of excess $\mathrm{O} 3, \mathrm{CO} 2, \mathrm{CO}, \mathrm{CH} 4, \mathrm{C} 2 \mathrm{H} 4, \mathrm{C} 2 \mathrm{H} 2, \mathrm{HCN}, \mathrm{NO}, \mathrm{NH} 3, \mathrm{HCOOH}, \mathrm{CH} 3 \mathrm{COOH}, \mathrm{HCHO}$, and $\mathrm{CH} 3 \mathrm{OH}$ in 1997 Alaskan biomass burning plumes by airborne Fourier transform infrared spectroscopy (AFTIR). J. Geophys. Res. 2000, 105, 22147-22166. 
The 1st International Electronic Conference on Atmospheric Sciences (ECAS 2016), 16-31 July 2016;

Sciforum Electronic Conference Series, Vol. 1, 2016

22. Akagi, S.K.; Yokelson, R.J.; Wiedinmyer, C.; Alvarado, M.J.; Reid, J.S.; Karl, T.; Crounse, J.D.; Wennberg, P.O. Emission factors for open and domestic biomass burning for use in atmospheric models. Atmos. Chem. Phys. Discuss. 2010, 10, 27523-27602.

23. Mcmeeking, G.R.; Kreidenweis, S.M.; Baker, S.; Carrico, C.M.; Chow, J.C.; Collett, J.L.; Hao, W.M.; Holden, A.S.; Kirchstetter, T.W.; Malm, W.C.; et al. Emissions of trace gases and aerosols during the open combustion of biomass in the laboratory. J. Geophys. Res. 2009, 114, doi:10.1029/2009JD011836.

24. R'honi, Y.; Clarisse, L.; Clerbaux, C.; Hurtmans, D.; Duflot, V.; Turquety, S.; Ngadi, Y.; Coheur, P.-F. Exceptional emissions of $\mathrm{NH}_{3}$ and $\mathrm{HCOOH}$ in the 2010 Russian wildfires. Atmos. Chem. Phys. Discuss. 2012, 12, 31561-31584.

25. Saylor, R.; Myles, L.; Sibble, D.; Caldwell, J.; Xing, J. Recent trends in gas-phase ammonia and PM 2.5 ammonium in the Southeast United States. J. Air Waste Man. Assoc. 2014, 65, 347-357.

26. Reinhard, M.; Rebetez, M.; Schlaepfer, R. Recent climate change: Rethinking drought in the context of Forest Fire Research in Ticino, South of Switzerland. Theor. Appl. Climatol. Theor. Appl. Climatol. 2005, 82, 17-25.

27. Piñol, J.; Terradas, J.; Lloret, F. Climate warming, wildfire hazard, and wildfire occurrence in coastal eastern Spain. Clim. Chang. 1998, 38, 345-357.

28. Liu, Y.; Goodrick, S.L.; Stanturf, J.A. Future U.S. wildfire potential trends projected using a dynamically downscaled climate change scenario. For. Ecol. Manag. 2013, 294, 120-135.

29. Westerling, A.L. Warming and Earlier Spring Increase Western U.S. Forest Wildfire Activity. Science 2006, 313, 940-943.

30. Gillett, N.P. Detecting the effect of climate change on Canadian forest fires. Geophys. Res. Lett. 2004, 31, 1-4.

31. Litschert, S.E.; Brown, T.C.; Theobald, D.M. Historic and future extent of wildfires in the Southern Rockies Ecoregion, USA. For. Ecol. Manag. 2012, 269, 124-133.

32. Skibba, R. Assessing U.S. Fire Risks Using Soil Moisture Satellite Data. Eos 2015, 96.

33. Zhu, L.; Henze, D.K.; Cady-Pereira, K.E.; Shephard, M.W.; Luo, M.; Pinder, R.W.; Bash, J.O.; Jeong, G.-R. Constraining U.S. ammonia emissions using TES remote sensing observations and the GEOS-Chem adjoint model. J. Geophys. Res. Atmos. 2013, 118, 3355-3368.

34. NASA Goddard Earth Sciences (GES) Data and Information Services Center (DISC), Atmospheric Infrared Sounder (AIRS) Documentation, Version 6 Documents. Available online: http://disc.sci.gsfc.nasa.gov/ AIRS/documentation (accessed on June 2016).

35. Battye, W.H.; Bray, C.D.; Aneja, V.P.; Tong, D.; Lee, P.; Tang, Y. Evaluating ammonia (NH3) predictions in the NOAA National Air Quality Forecast Capability (NAQFC) using in situ aircraft, ground-level, and satellite measurements from the DISCOVER-AQ Colorado campaign. Atmos. Environ. 2016, 140, 342-351.

36. Radiello. Available online: http://www.radiello.com/english/nh3_en.htm (accessed on June 2016).

37. NADP Ammonia Monitoring Network Standard Operating Procedures. Available online: http://nadp. sws.uiuc.edu/AMoN/amon-standardoperatingprocedures.pdf (accessed on June 2016).

38. Davies, D.; Ilavajhala, S.; Wong, M.M.; Justice, C. Fire Information for Resource Management System: Archiving and Distributing MODIS Active Fire Data. IEEE Trans. Geosci. Remote Sens. IEEE Trans. Geosci. Remote Sens. 2009, 47, 72-79.

39. Wiedinmyer, C.; Quayle, B.; Geron, C.; Belote, A.; Mckenzie, D.; Zhang, X.; O’Neill, S.; Wynne, K.K. Estimating emissions from fires in North America for air quality modeling. Atmos. Environ. 2006, 40, 34193432.

40. Wiedinmyer, C.; Akagi, S.K.; Yokelson, R.J.; Emmons, L.K.; Al-Saadi, J.A.; Orlando, J.J.; Soja, A.J. The Fire INventory from NCAR (FINN): A high resolution global model to estimate the emissions from open burning. Geosci. Model. Dev. 2011, 4, 625-641.

41. Oliveras, I.; Anderson, L.O.; Malhi, Y. Application of remote sensing to understanding fire regimes and biomass burning emissions of the tropical Andes. Glob. Biogeochem. Cycles 2014, 28, 480-496.

42. Roy, D.; Boschetti, L. Southern Africa Validation of the MODIS, L3JRC, and GlobCarbon Burned-Area Products. IEEE Trans. Geosci. Remote Sens. 2009, 47, 1032-1044.

43. Ito, A.; Penner, J.E. Global estimates of biomass burning emissions based on satellite imagery for the year 2000. J. Geophys. Res. 2004, 109, doi:10.1029/2003JD004423.

44. University of Maryland Global Land Cover Facility. Available online: www.glcf.umb.edu/data/treecover (accessed on June 2016). 
The 1st International Electronic Conference on Atmospheric Sciences (ECAS 2016), 16-31 July 2016;

Sciforum Electronic Conference Series, Vol. 1, 2016

45. US EPA NEI. Available online: https://www.epa.gov/air-emissions-inventories/2011-national-emissionsinventory-nei-data) (accessed on June 2016).

46. Menne, M.J.; Durre, I.; Vose, R.S.; Gleason, B.E.; Houston, T.G.An Overview of the Global Historical Climatology Network-Daily Database. J. Atmos. Ocean. Technol. J. Atmos. Ocean. Technol. 2012, 29, 897-910.

47. Menne, M.J.; Durre, I.; Korzeniewski, B.; McNeal, S.; Thomas, K.; Yin, X.; Anthony, S.; Ray, R.; Vose, R.S.; Gleason, B.E.; Houston, T.G. NOAA National Climatic Data Center. Global Historical Climatology Network-Daily (GHCN-Daily), Version 3. Available online: http://doi.org/10.7289/V5D21VHZ (accessed on June 2016).

48. Butler, T.; Vermeylen, F.; Lehmann, C.; Likens, G.; Puchalski, M. Increasing ammonia concentration trends in large regions of the USA derived from the NADP/AMoN network. Atmos. Environ. 2016, in press.

49. Whitburn, S.; Van Damme, M.; Kaiser, J.W.; Van Der Werf, G.R.; Turquety, S.; Hurtmans, D.; Clarisse, L.; Clerbaux, C.; Coheur, P.F. Ammonia emissions in tropical biomass burning regions: Comparison between satellite-derived emissions and bottom-up fire inventories. Atmos. Environ. 2015, 121, 42-54.

50. Ichoku, C.; Ellison, L. Global top-down smoke-aerosol emissions estimation using satellite fire radiative power measurements. Atmos. Chem. Phys. 2014, 14, 6643-6667.

(C) 2016 by the authors; licensee MDPI, Basel, Switzerland. This article is an open access article distributed under the terms and conditions of the Creative Commons by Attribution (CC-BY) license (http://creativecommons.org/licenses/by/4.0/). 